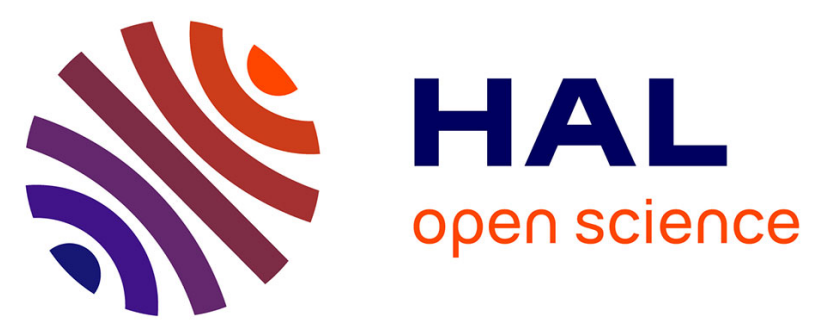

\title{
Linear and three-arm star hydroxytelechelic poly(benzyl $\beta$-malolactonate)s: a straightforward one-step synthesis through ring-opening polymerization
}

\author{
Ghislaine Barouti, Cedric G. Jaffredo, Sophie M Guillaume
}

\section{To cite this version:}

Ghislaine Barouti, Cedric G. Jaffredo, Sophie M Guillaume. Linear and three-arm star hydroxytelechelic poly(benzyl $\beta$-malolactonate)s: a straightforward one-step synthesis through ring-opening polymerization. Polymer Chemistry, 2015, 6 (32), pp.5851-5859. 10.1039/C5PY00724K . hal01188240

HAL Id: hal-01188240

https://hal-univ-rennes1.archives-ouvertes.fr/hal-01188240

Submitted on 17 Sep 2015

HAL is a multi-disciplinary open access archive for the deposit and dissemination of scientific research documents, whether they are published or not. The documents may come from teaching and research institutions in France or abroad, or from public or private research centers.
L'archive ouverte pluridisciplinaire HAL, est destinée au dépôt et à la diffusion de documents scientifiques de niveau recherche, publiés ou non, émanant des établissements d'enseignement et de recherche français ou étrangers, des laboratoires publics ou privés. 
Linear and Three arm Hydroxytelechelic Poly(Benzyl $\beta$-Malolactonate)s:

A Straightforward One-step Synthesis through Ring-Opening Polymerization

Ghislaine Barouti, ${ }^{\S}$ Cédric G. Jaffredo, ${ }^{\S}$ and Sophie M. Guillaume*

Institut des Sciences Chimiques de Rennes, UMR 6226 CNRS - Université de Rennes 1, Campus de Beaulieu, F-35042 Rennes Cedex, France

\footnotetext{
$\S$ Equally contributing first authors

* Corresponding author: sophie.guillaume@univ-rennes1.fr
} 


\section{Graphical abstract}

\section{PMLA $^{\mathrm{Be}}$-nol in one step!}

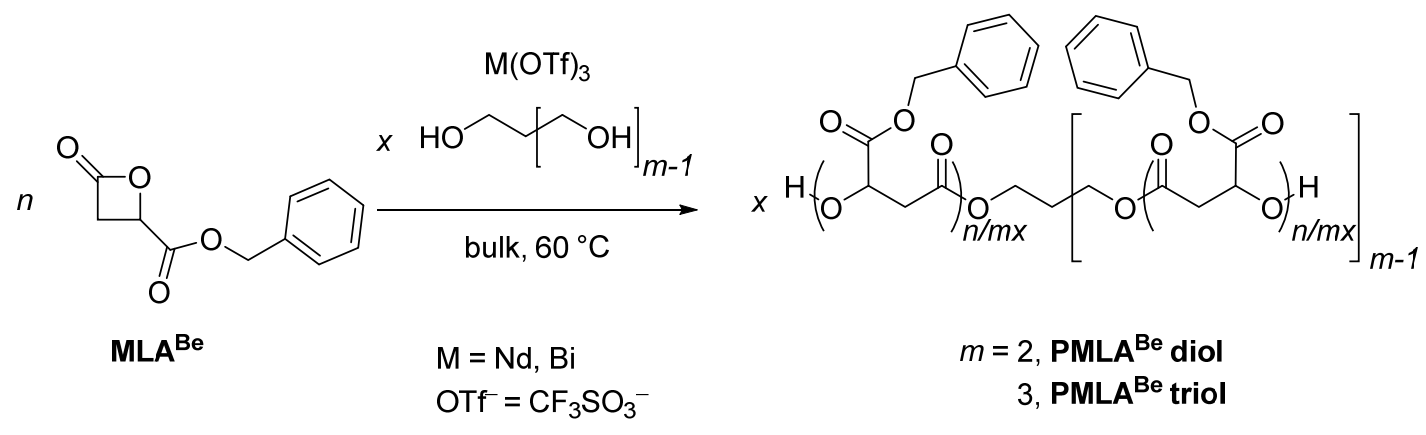




\section{Abstract}

Ring-opening polymerization (ROP) of racemic-benzyl $\beta$-malolactonate $\left(\mathrm{MLA}^{\mathrm{Be}}\right)$ initiated by an alcohol such as 1,3-propanediol (PPD) or 2-hydroxymethyl-1,3-propanediol (TMM), and catalyzed by a metal triflate $\mathrm{M}(\mathrm{OTf})_{3}$ with $\mathrm{M}=\mathrm{Nd}, \mathrm{Bi}$, proceeded under mild operating conditions (in bulk at $60^{\circ} \mathrm{C}$ ). The functionality of the alcohol dictates the topology of the resulting hydroxyl telechelic PMLA ${ }^{\mathrm{Be}}$. The ROP promoted by the neodymium-based catalytic system afforded a satisfactory activity and control in terms of molar mass and dispersity values $\left(M_{\mathrm{n}, \mathrm{NMR}}\right.$ up to $\left.7000 \mathrm{~g} \cdot \mathrm{mol}^{-1}, \bigoplus_{\mathrm{M}}<1.35\right)$. Mechanistic insights revealed that ring-opening of $\mathrm{MLA}^{\mathrm{Be}}$ took place through the selective oxygen-acyl bond cleavage without undesirable side reactions such as transesterification or crotonisation, as evidenced by NMR and mass spectrometry analyses of the recovered polyesters. The structure of the corresponding $\alpha, \omega$-hydroxy telechelic PMLA ${ }^{\mathrm{Be}} \mathrm{s}$ was ascertained by ${ }^{1} \mathrm{H}$ and ${ }^{13} \mathrm{C}\left\{{ }^{1} \mathrm{H}\right\} \mathrm{NMR}$, SEC, and MALDI-ToF mass spectrometry analyses. In comparison, methane and trifluoromethane sulfonic acids did not allow the formation of well-defined PMLA ${ }^{\mathrm{Be}}$ diols. Differences in the behavior of $\mathrm{MLA}^{\mathrm{Be}}$ and the related $\beta$-butyrolactone are highlighted. The present $\mathrm{Nd}(\mathrm{OTf})_{3} / \mathrm{PPD}$ or TMM catalytic ROP of $\mathrm{MLA}^{\mathrm{Be}}$ thus represents a valuable direct synthesis of PMLA ${ }^{\mathrm{Be}}$ diols and triols, respectively, without requiring chemical modification of a preformed PMLA ${ }^{\mathrm{Be}}$ precursor.

Keyword: hydroxy telechelic polymer, PHA, polyester, poly(hydroxyalkanoate), polymer diol, ring-opening polymerization (ROP), poly(benzyl $\beta$-malolactonate) (PMLA ${ }^{\mathrm{Be}}$ ) 


\section{Introduction}

Hydroxy telechelic polymers are highly valuable building blocks for both academic and industrial applications. They are widely used as elementary constituents for the elaboration of copolymers combining other monomer(s) with various architectures (linear, star, branched, comb), by step-growth polymerization. In particular, one major valorization of polyols lies in the preparation of polyurethanes upon reaction of the reactive hydroxyl endgroups with poly(isocyanate)s, a major market in polymers manufacturing. ${ }^{1,2,3,4}$

Poly(hydroxyalkanoate)s (PHAs) are biocompatible and (bio)degradable aliphatic polyesters which are being developed for their applications as commodity plastics, as well as in the environment, and in the medical field. ${ }^{5,6,7,8,9,10,11,12,13}$ One major drawback of natural PHAs, although quite extensively investigated, is their still unsatisfactorily productive preparation method from bacterial fermentation process, and their limited thermo-mechanical properties which somewhat restrain their extensive use. In this regard, the development of ring-opening polymerization (ROP) of four-membered ring cyclic $\beta$-lactones towards the formation of synthetic PHAs, enables to tackle both issues. Indeed, one can synthesize the monomers featuring the desired substituents on the $\beta$-position of the lactone. Next, provided the suitable efficient catalytic system is implemented, one can most conveniently access by ROP to finely tuned PHAs with adjusted chemical, macromolecular (in particular targeted molar mass values, low dispersity $\left(\bigoplus_{\mathrm{M}}=M_{\mathrm{w}} / M_{\mathrm{n}}\right)$, evidence of limited undesirable side reactions (transesterification and transfer reactions), chain-end fidelity, microstructure - i.e. tacticity, hydrophilicity, degradation), and physical (especially thermal transition temperatures, crystallinity, elasticity) characteristics. ${ }^{14,15,16}$ Whereas the most common and ubiquitous PHA is poly(3-hydroxybutyrate) (PHB; derived by ROP from $\beta$-butyrolactone (BL) which bears a methyl substituent), ${ }^{14,15,16}$ the importance of poly(benzyl $\beta$-malolactonate) $\left(\right.$ PMLA $\left.^{\mathrm{Be}}\right)$ and its parent benzyl-deprotected poly(malic acid) (PMLA), has significantly 
grown over the past few years. ${ }^{17,18,19,20,21,22}$ Indeed, these latter two PHA members are synthesized by ROP of benzyl $\beta$-malolactone $\left(\mathrm{MLA}^{\mathrm{Be}}\right)$ followed by abstraction of the $\beta$-benzyloxycarbonyl substituents upon hydrogenolysis, respectively (Scheme 1). ${ }^{14-21}$ The significant advantage of PMLA ${ }^{\mathrm{Be}} / \mathrm{PMLA}$ is that they are derived from aspartic or malic acids, two bio-renewable sugar-derived components listed in the top ten value-added chemicals established by the US Department Of Energy. ${ }^{18-20,23,24}$ In this regard, MLA ${ }^{\mathrm{Be}}$ and PMLA ${ }^{\mathrm{Be}}$ thus appear as potential valuable environmentally-friendly (bio)degradable alternatives to commodity plastics such as petrochemical polyolefins. Thanks to their biocompatibility, PMLA $^{\mathrm{Be}}$ and PMLA are also used in the biomedical field. ${ }^{21,22,25}$ The ease of the chemical modification of hydrophobic PMLA $^{\mathrm{Be}}$ into its hydrophilic PMLA homologue upon hydrogenolysis under mild conditions $\left(\mathrm{H}_{2}, \quad \mathrm{Pd} / \mathrm{C}, \quad 23^{\circ} \mathrm{C}\right)$ without backbone alteration, ${ }^{18,20,21,25,26}$ and the availability of the thereby resulting $-\mathrm{CO}_{2} \mathrm{H}$ as anchoring sites for biologically active molecules, ${ }^{27,28}$ is a rather unique characteristic among PHAs which is attracting much consideration, in particular for the design of amphiphilic self-assembling PMLA-based copolymers as drug delivery systems. ${ }^{17-22,25,29}$

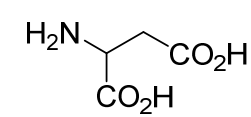

rac-Aspartic acid<smiles>O=C(O)CC(O)C(=O)O</smiles>

rac-Malic acid
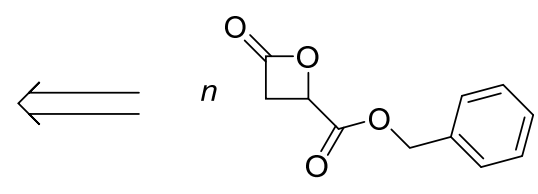

rac-MLA ${ }^{B e}$

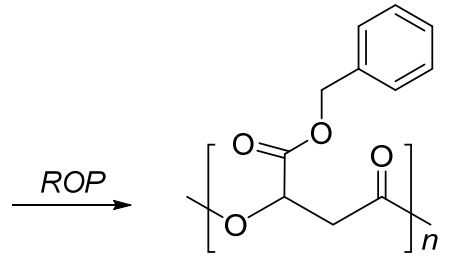

PMLA ${ }^{B e}$

Scheme 1. Synthesis of poly(benzyl $\beta$-malolactonate) $\left(\mathrm{PMLA}^{\mathrm{Be}}\right)$ by ROP of benzyl $\beta$-malolactonate $\left(\mathrm{MLA}^{\mathrm{Be}}\right)$.

The past decade has witnessed a resurgence of interest in the ROP of MLA ${ }^{\mathrm{Be}}$ to synthesize $\operatorname{PMLA}^{(\mathrm{Be})}$ (co)polymers. ${ }^{17-21}$ Besides the purely cationic and anionic 
catalysts/initiators used in earlier investigations, recent catalytic systems based on either organic components such as guanidines, amidines, or phosphazenes, or discrete metal derivatives, have been demonstrated as effective for the preparation of PMLA ${ }^{\text {Be }}$ (co)polymers. ${ }^{20,30}$ To our knowledge, only a few metal-catalyzed ROPs of MLA ${ }^{\text {Be }}$ have been reported. Apart from the first established $O$-methoxy tetraphenylporphyrin aluminium ((TPP)Al $\left.\left(\mathrm{OCH}_{3}\right)\right),{ }^{31}$ methylaluminoxane (MAO), ethylaluminoxane (EAO), ${ }^{32,33}$ and tin(II) bis(2-ethylhexanoate) $\left(\mathrm{Sn}(\text { octoate })_{2}=\mathrm{SnOct}_{2}\right)^{34}$ ones, the more recently unveiled zinc $\beta$-diketiminate compound $\left[(\mathrm{BDI}) \mathrm{Zn}\left(\mathrm{N}\left(\mathrm{SiMe}_{3}\right)_{2}\right)\right] \quad\left(\mathrm{BDI}=\mathrm{CH}\left(\mathrm{CMeNC}_{6} \mathrm{H}_{3}-2,6-{ }^{i} \mathrm{Pr}_{2}\right)_{2}\right)$ or $\mathrm{M}(\mathrm{OTf})_{3}$ (with $\mathrm{M}=\mathrm{Al}, \mathrm{Nd}, \mathrm{OTf}^{-}=\mathrm{CF}_{3} \mathrm{SO}_{3}{ }^{-}$) associated to an alcohol (typically isopropanol $(i \mathrm{PrOH})$ or benzyl alcohol $(\mathrm{BnOH}))$, or the in situ generated yttrium isopropoxide complex supported by a tetradentate dichloro-substituted bis(phenolate) ligand, promoted the ROP of $\mathrm{MLA}^{\mathrm{Be}}$ at $20-60^{\circ} \mathrm{C}$ in bulk monomer, affording well-defined linear $\alpha$-hydroxy, $\omega$-alkoxycarbonyl telechelic PMLA ${ }^{\mathrm{Be}} \mathrm{S}^{26,35,36}$

Polymer diols are often prepared upon post-polymerization chemical modification of a mono-hydroxyl end-capped polymer. The main reason is that direct synthetic routes to $\alpha, \omega$-dihydroxy telechelic polymers are less often encountered. ${ }^{4}$ The first example of PMLA ${ }^{\mathrm{Be}}$ diol has thus been obtained by chemical transformation of a preformed $\alpha$-hydroxy, $\omega$-carboxylic acid PMLA ${ }^{\mathrm{Be}}$ sample. ${ }^{37}$ More recently, we evidenced the straightforward onestep synthesis of $\mathrm{PMLA}^{\mathrm{Be}}$ diol by ROP of $\mathrm{MLA}^{\mathrm{Be}}$ using rare earth borohydride initiators, $\mathrm{Ln}\left(\mathrm{BH}_{4}\right)_{3}(\mathrm{THF})_{3}(\mathrm{Ln}=\mathrm{La}, \mathrm{Nd}, \mathrm{Sm})$, a strategy similarly implemented to access PHB diols. ${ }^{38,39,40,41,42}$ The one drawback of this approach is the sensitivity of these rare earth borohydride complexes to air and moisture. Therefore, a more convenient (easy to handle) initiator and a more straightforward strategy are desirable for the synthesis of hydroxy telechelic PMLA ${ }^{\mathrm{Be}}$. 
To that end, given the successful synthesis of BnO-PMLA ${ }^{\mathrm{Be}}-\mathrm{OH}$ by ROP of MLA ${ }^{\mathrm{Be}}$ with $\mathrm{Al}(\mathrm{OTf})_{3} / \mathrm{BnOH},{ }^{35}$ and the efficiency of catalyst systems derived from metal triflates $\mathrm{M}(\mathrm{OTf})_{3} /{ }^{\mathrm{i}} \mathrm{PrOH}(\mathrm{M}=\mathrm{Nd}, \mathrm{Bi})$ to promote the copolymerization of $\mathrm{MLA}^{\mathrm{Be}}$ and $\mathrm{BL},{ }^{36}$ metal triflates combined to several higher alcohols such as 1,3-propanediol (PPD), and 2-hydroxymethyl-1,3-propanediol (tris(hydroxymethyl)methane (trimethylolmethane, TMM), were thus investigated in the present study towards the synthesis of $\operatorname{PMLA}^{\mathrm{Be}}-n$-ols (Scheme 2). Also, the reported synthesis of the related PHB and PHB diol from the ROP of BL catalyzed by trifluoromethane $e^{43,44,45}$ and methane sulfonic ${ }^{45}$ acids (HOTf and MSA, respectively) in combination to an alcohol or diol initiator, prompted the similar investigation of these related organic sulfonic acids in the preparation of PMLA ${ }^{\mathrm{Be}}-n$-ols. The $\alpha, \omega$-hydroxy telechelic PMLA ${ }^{\mathrm{Be}} \mathrm{s}$ were characterized by ${ }^{1} \mathrm{H},{ }^{13} \mathrm{C}\left\{{ }^{1} \mathrm{H}\right\}$ NMR, SEC, and MALDI-ToF mass spectrometry analyses.

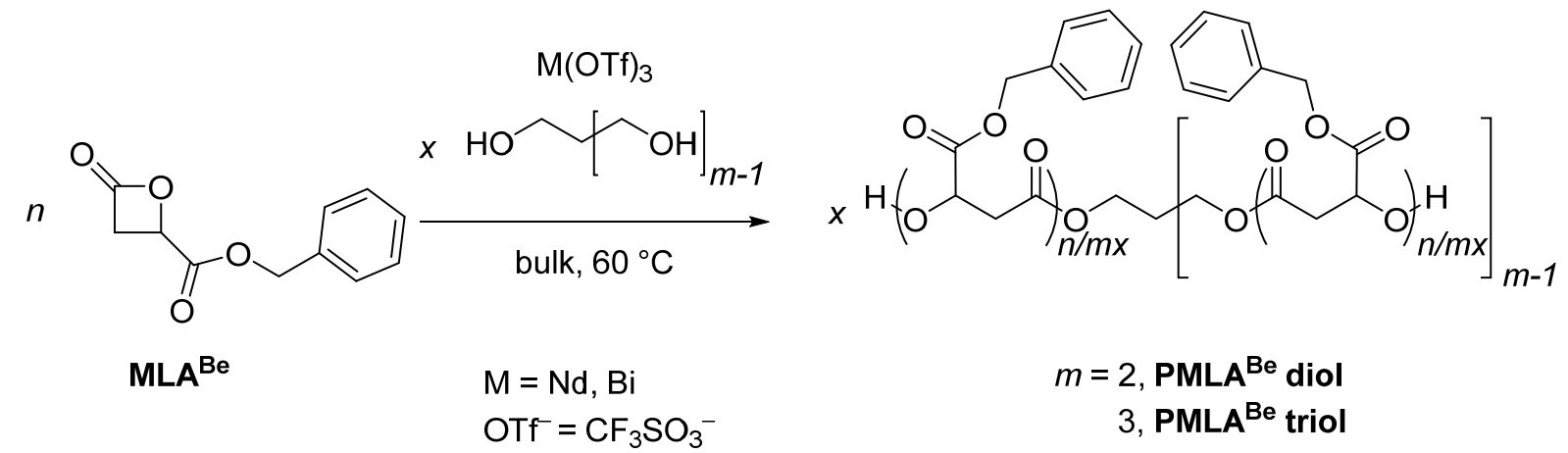

Scheme 2. Synthesis of PMLA ${ }^{\mathrm{Be}}-n$-ols by ROP of $\mathrm{MLA}^{\mathrm{Be}}$ from metal triflate/alcohol systems.

\section{Experimental section}

\section{Methods and Materials}

All polymerizations were performed under inert atmosphere (argon) using standard Schlenk, vacuum line, and glove box techniques. Racemic benzyl $\beta$-malolactone (MLA ${ }^{\mathrm{Be}}$ ) was synthesized from $(R, S)$-aspartic acid according to the reported procedure. ${ }^{29}$ Metal triflates $\mathrm{M}(\mathrm{OTf})_{3}$ with $\mathrm{M}=\mathrm{Nd}, \mathrm{Bi}$, trifluoromethanesulfonic acid (triflic acid, HOTf, $\geq 99 \%$ ), 
methanesulfonic acid (MSA, > 98\%, Alfa Aesar), 1,3 propanediol (PPD, 98\%), 2-hydroxymethyl-1,3-propanediol (tris(hydroxymethyl)methane, or trimethylolmethane, TMM, 97\%), and all other reagents were used as received (Aldrich unless otherwise mentioned).

\section{Instrumentation and measurements}

${ }^{1} \mathrm{H}(500$ and $400 \mathrm{MHz})$ and ${ }^{13} \mathrm{C}\left\{{ }^{1} \mathrm{H}\right\}(125$ and $100 \mathrm{MHz})$ NMR spectra were recorded on Bruker Avance AM 500 and Ascend 400 spectrometers at $25^{\circ} \mathrm{C}$. Chemical shifts $(\delta)$ are reported in ppm and were referenced internally relative to tetramethylsilane ( $\delta 0 \mathrm{ppm})$ using the residual ${ }^{1} \mathrm{H}$ and ${ }^{13} \mathrm{C}$ solvent resonances. Note that the ${ }^{1} \mathrm{H}$ NMR spectra of PMLA ${ }^{\mathrm{Be}}$ systematically featured broadened signals (typically $v_{1 / 2}=c a$. $26 \mathrm{~Hz}$ ), as commonly encountered in the literature. ${ }^{30,35-38}$

Size-exclusion chromatography (SEC) giving number-average molar mass $\left(M_{\mathrm{n}, \mathrm{SEC}}\right)$ and dispersity $\left(\bigoplus_{\mathrm{M}}=M_{\mathrm{w}} / M_{\mathrm{n}}\right)$ values of the $\mathrm{PMLA}^{\mathrm{Be}} \mathrm{s}$ was carried out in THF at $30^{\circ} \mathrm{C}$ (flow rate $1.0 \mathrm{~mL} \cdot \mathrm{min}^{-1}$ ) on a Polymer Laboratories PL50 apparatus equipped with a refractive index detector and a set of two ResiPore PLgel $3 \mu \mathrm{m}$ MIXED-D $300 \times 7.5 \mathrm{~mm}$ columns. The polymer samples were dissolved in THF $\left(2 \mathrm{mg} \cdot \mathrm{mL}^{-1}\right)$. All elution curves were calibrated with 11 monodisperse polystyrene standards $\left(M_{\mathrm{n}}\right.$ range $\left.=580-380,000 \mathrm{~g} \cdot \mathrm{mol}^{-1}\right)$; all $M_{\mathrm{n}, \mathrm{SEC}}$ values of the PMLA ${ }^{\mathrm{Be}} \mathrm{s}$ were uncorrected for their potential difference in hydrodynamic radius $v s$. polystyrene. The SEC traces of the polymers all exhibited a non-Gaussian shaped peak tailing at longer elution times, inducing relatively large dispersities which yet remained below 1.58 . The $M_{\mathrm{n}, \mathrm{SEC}}$ values thus obtained often remained lower than the calculated values or the values determined by NMR $\left(M_{\mathrm{n}, \mathrm{NMR}}\right.$, vide infra $)$.

Monomer conversions were determined from ${ }^{1} \mathrm{H}$ NMR spectra of the crude polymer samples, from the integration (Int.) ratio Int.PMLABe/[Int.PMLABe + Int.MLABe $_{\text {, }}$, using the methine hydrogens $-\mathrm{CH}_{2} \mathrm{CH}\left(\mathrm{CO}_{2} \mathrm{Be}\right) \mathrm{O}\left(\delta_{\mathrm{PMLABe}}=5.50-5.55 \mathrm{ppm}, \delta_{\mathrm{MLABe}}=4.88 \mathrm{ppm}\right)$. 
The molar mass values of PMLA ${ }^{\mathrm{Be}}$ samples were determined by ${ }^{1} \mathrm{H}$ NMR analysis in $\mathrm{CDCl}_{3}$ from the relative intensities of the signals of the main-chain methylene hydrogens $\left(\delta_{\mathrm{CH} 2 \mathrm{CH}(\mathrm{CO} 2 \mathrm{Be})}=2.92 \mathrm{ppm}\right)$, relative to the methylene hydrogens $\left(\delta_{\mathrm{CH}(\mathrm{CH} 2 \mathrm{O}) \mathrm{x}}=c a .4 .00-4.20\right.$, 1.80-2.10 ppm) of the PPD $(\mathrm{x}=2)$, or TMM $(\mathrm{x}=3)$ initiator $($ Table 1). The good resolution of the signals of the chain-end groups allowed their fairly reliable integration (Figures 2, 4, $\mathrm{S} 1-\mathrm{S} 2)$. The number-average molar mass values thus obtained by ${ }^{1} \mathrm{H}$ NMR $\left(M_{\mathrm{n}, \mathrm{NMR}}\right)$ were in close agreement with the ones calculated $\left(M_{\mathrm{n}, \text { theo }}\right)$, as reported in Table 1.

MALDI-ToF mass spectra were recorded at the CESAMO (Bordeaux, France) on a Voyager mass spectrometer (Applied Biosystems) equipped with a pulsed $\mathrm{N}_{2}$ laser source $(337 \mathrm{~nm})$ and a time-delayed extracted ion source. Spectra were recorded in the positive-ion mode using the reflectron mode and with an accelerating voltage of $20 \mathrm{kV}$. A THF solution (1 $\mathrm{mL}$ ) of the matrix (ditranol, Aldrich, $99 \%$ ) and a $\mathrm{MeOH}$ solution of the cationisation agent (NaI, (10 mg.mL $\left.\left.{ }^{-1}\right)\right)$ were prepared. A fresh solution of the polymer sample in THF (10 mg. $\mathrm{mL}^{-1}$ ) was then prepared. The three solutions were next rapidly combined in a $1: 1: 10$ volume ratio of matrix-to-sample-to-cationisation agent. One to two microliters of the resulting solution were deposited onto the sample target and vacuum-dried.

Typical MLA $^{\text {Be }}$ homopolymerization. In a typical experiment (Table 1, entry 5), Nd(OTf) (10 mg, $16.9 \mu \mathrm{mol})$ and a solution of 1,3 propanediol (PPD, $6.1 \mu \mathrm{L}, 84.5 \mu \mathrm{mol}, 5$ equiv vs. $\left.\mathrm{Nd}(\mathrm{OTf})_{3}\right)$ in toluene $(0.1 \mathrm{~mL}$; in light of this small volume, the polymerization can be considered as a bulk procedure) were charged in a Schlenk flask in the glove box, prior to the addition of $\mathrm{MLA}^{\mathrm{Be}}\left(0.35 \mathrm{~g}, 1.69 \mathrm{mmol}, 100\right.$ equiv). The mixture was then stirred at $60{ }^{\circ} \mathrm{C}$ for the appropriate reaction time (reaction times were not systematically optimized). The polymerization was quenched by addition of acetic acid $\left(c a .10 \mu \mathrm{L}\right.$ of a $1.6 \mathrm{~mol} \cdot \mathrm{L}^{-1}$ solution in toluene). The resulting mixture was concentrated to dryness under vacuum and the conversion was determined by ${ }^{1} \mathrm{H}$ NMR analysis of the residue in $\mathrm{CDCl}_{3}$. The crude polymer 
was then dissolved in $\mathrm{CH}_{2} \mathrm{Cl}_{2}(2 \mathrm{~mL})$ and precipitated in cold pentane $(10 \mathrm{~mL})$, filtered and dried under vacuum at $45{ }^{\circ} \mathrm{C}$ overnight (typical isolated yield $90-95 \%$ ). The final polymer was then analyzed by NMR, SEC and MALDI-ToF analyses (Table 1).

PMLA $^{\text {Be }}$ diol : ${ }^{1} \mathrm{H}$ NMR $\left(500 \mathrm{MHz} ; \mathrm{CDCl}_{3}, 25^{\circ} \mathrm{C}\right): \delta 7.30$ (br m, 5n, $\mathrm{C}_{6} \mathrm{H}_{5}$ ), 5.50 (br m, 1nH, $\mathrm{CH}_{2} \mathrm{CH}\left(\mathrm{CO}_{2} \mathrm{Be}\right) \mathrm{O}$ ), 5.12 (br s, 2nH, OCH $\left.\mathrm{C}_{6} \mathrm{H}_{5}\right), 4.18$ (br m, 4H, $\left.\mathrm{CH}_{2}\left(\mathrm{CH}_{2} \mathrm{OPMLA}^{\mathrm{Be}}\right)_{2}\right), 3.63$ (br s, 2H, OH), 2.92 (br m, 2nH, $\left.\mathrm{CHCH}_{2} \mathrm{C}(\mathrm{O}) \mathrm{O}\right), 1.80$ (br m, 2H, $\mathrm{CH}_{2}\left(\mathrm{CH}_{2} \mathrm{OPMLA}^{\mathrm{Be}}\right)_{2}$ ) (Figure 2). ${ }^{13} \mathrm{C}\left\{{ }^{1} \mathrm{H}\right\}$ NMR $\left(125 \mathrm{MHz} ; \mathrm{CDCl}_{3}, 25^{\circ} \mathrm{C}\right): \delta 168.1(C=\mathrm{O}), 134.9(C 8), 126.6-$ $127.0 \quad(C 9-11), \quad 68.5 \quad\left(\mathrm{OCH}\left(\mathrm{CO}_{2} \mathrm{Be}\right) \mathrm{CH}_{2} \mathrm{C}(\mathrm{O})\right), \quad 67.7 \quad\left(\mathrm{OCH}_{2} \mathrm{C}_{6} \mathrm{H}_{5}\right), \quad 65.4$ $\left(\mathrm{CH}_{2}\left(\mathrm{CH}_{2} \mathrm{OPMLA}^{\mathrm{Be}}\right)_{2}\right), 38.6\left(\mathrm{CH}_{2}\left(\mathrm{CH}_{2} \mathrm{OPMLA}^{\mathrm{Be}}\right)_{2}\right), 35.5\left(\mathrm{OC}(\mathrm{O}) \mathrm{CH}_{2} \mathrm{CH}\right)$, (Figure 3). MALDI-ToF MS (Figure 6).

PMLA $^{\text {Be }}$ triol : ${ }^{1} \mathrm{H}$ NMR $\left(500 \mathrm{MHz} ; \mathrm{CDCl}_{3}, 25^{\circ} \mathrm{C}\right): \delta 7.30$ (br m, 5n, $\left.\mathrm{C}_{6} \mathrm{H}_{5}\right), 5.50$ (br m, 1nH, $\mathrm{CH}_{2} \mathrm{CH}\left(\mathrm{CO}_{2} \mathrm{Be}\right) \mathrm{O}$ ), 5.12 (br m, 2nH, $\mathrm{OCH}_{2} \mathrm{C}_{6} \mathrm{H}_{5}$ ), 4.52 (br s, 3H, OH), 4.06 (br m, 4H, $\left.\mathrm{CH}\left(\mathrm{CH}_{2} \mathrm{OPMLA}^{\mathrm{Be}}\right)_{3}\right), \quad 2.92 \quad\left(\mathrm{br} \quad \mathrm{m}, \quad 2 \mathrm{nH}, \quad \mathrm{CHCH}_{2} \mathrm{C}(\mathrm{O}) \mathrm{O}\right), 2.05 \quad(\mathrm{br} \quad \mathrm{m}, \quad 2 \mathrm{H}$, $\left.\mathrm{CH}\left(\mathrm{CH}_{2} \mathrm{OPMLA}{ }^{\mathrm{Be}}\right)_{2}\right)$ (Figure 4). ${ }^{13} \mathrm{C}\left\{{ }^{1} \mathrm{H}\right\}$ NMR (125 MHz; $\left.\mathrm{CDCl}_{3}, 25{ }^{\circ} \mathrm{C}\right): \delta 172.8-168.2$ $(C=\mathrm{O}), 135.1(C 8), 128.7-128.3(C 9-11), 68.8\left(\mathrm{OCH}\left(\mathrm{CO}_{2} \mathrm{Be}\right) \mathrm{CH}_{2} \mathrm{C}(\mathrm{O})\right), 67.7\left(\mathrm{OCH}_{2} \mathrm{C}_{6} \mathrm{H}_{5}\right)$, $67.4\left(\mathrm{CH}\left(\mathrm{CH}_{2} \mathrm{OPMLA}^{\mathrm{Be}}\right)_{3}\right), 38.7\left(\mathrm{CH}\left(\mathrm{CH}_{2} \mathrm{OPMLA}^{\mathrm{Be}}\right)_{3}\right), 35.4\left(\mathrm{OC}(\mathrm{O}) \mathrm{CH}_{2} \mathrm{CH}\right)$, (Figure 5). MALDI-TOF MS (Figure 7).

\section{Results and Discussion}

ROP of $M^{\text {BeA }}{ }^{\mathrm{Be}}$ promoted by metal triflates, trifluoromethane and methane sulfonic acids. The ring-opening polymerization (ROP) of racemic-MLA ${ }^{\mathrm{Be}}\left(\mathrm{MLA}^{\mathrm{Be}}\right)$ was investigated using $\mathrm{M}(\mathrm{OTf})_{3}$ with $\mathrm{M}=\mathrm{Nd}, \mathrm{Bi}$, or trifluoromethane and methane sulfonic acids (HOTf and MSA, respectively) as catalyst, in association with 1,3 propanediol (PPD), or 2-hydroxymethyl-1,3-propanediol (tris(hydroxymethyl)methane or trimethylolmethane (TMM)), under a standard set of conditions viz. in bulk at $60^{\circ} \mathrm{C}$ (refer to the Experimental 
Section). The most significant data are gathered in Table 1. In order to get low molar mass samples suitable for NMR spectroscopy and MALDI-ToF mass spectrometry analyses (vide infra), the alcohol was used in excess (5 equiv.) under immortal ROP conditions. ${ }^{46,47}$

Table 1. ROP of $\mathrm{MLA}^{\mathrm{Be}}$ catalyzed by $\mathrm{M}(\mathrm{OTf})_{3}$ with $\mathrm{M}=\mathrm{Nd}, \mathrm{Bi}$, or $\mathrm{MSA}$, in presence of PPD or TMM initiator. ${ }^{\mathrm{a}}$

\begin{tabular}{|c|c|c|c|c|c|c|c|c|c|}
\hline Entry & Catalyst & Initiator & $\begin{array}{l}{\left[\mathrm{MLA}^{\mathrm{Be}}\right]_{0}:} \\
{[\text { Catalyst }]_{0} \text { : }} \\
{[\text { Initiator }]_{0}{ }^{\mathrm{a}}}\end{array}$ & $\begin{array}{c}\text { Reaction } \\
\text { Time }^{\text {b }} \\
\text { (h) }\end{array}$ & $\begin{array}{c}\text { MLA }^{\mathrm{Be}} \\
\text { Conv. }^{\mathrm{c}} \\
(\%)\end{array}$ & $\begin{array}{c}M_{\mathrm{n}, \text { theo }}{ }^{\mathrm{d}} \\
\left(\mathrm{g} \cdot \mathrm{mol}^{-1}\right)\end{array}$ & $\begin{array}{c}M_{\mathrm{n}, \mathrm{NMR}}{ }^{\mathrm{e}} \\
\left(\mathrm{g} \cdot \mathrm{mol}^{-1}\right)\end{array}$ & $\begin{array}{c}M_{\mathrm{n}, \mathrm{SEC}}{ }^{\mathrm{f}} \\
\left(\mathrm{g} \cdot \mathrm{mol}^{-1}\right)\end{array}$ & $\boldsymbol{D}_{M}^{\mathrm{g}}$ \\
\hline 1 & $\mathrm{Bi}(\mathrm{OTf})_{3}$ & PPD & $50: 1: 5$ & 1 & 100 & 2100 & 1200 & 1000 & 1.34 \\
\hline 2 & $\mathrm{Bi}(\mathrm{OTf})_{3}$ & PPD & 100:1:5 & 2 & 100 & 4200 & 1400 & 1200 & 1.43 \\
\hline 3 & $\mathrm{Bi}(\mathrm{OTf})_{3}$ & PPD & 200:1:5 & 4 & 91 & 7600 & 1900 & 1100 & 1.39 \\
\hline 4 & $\mathrm{Nd}(\mathrm{OTf})_{3}$ & PPD & $10: 1: 2$ & 12 & 100 & 1100 & 1000 & 800 & 1.18 \\
\hline 5 & $\mathrm{Nd}(\mathrm{OTf})_{3}$ & PPD & $20: 1: 2$ & 16 & 83 & 1700 & 1800 & 1000 & 1.36 \\
\hline 6 & $\mathrm{Nd}(\mathrm{OTf})_{3}$ & PPD & $50: 1: 5$ & 16 & 93 & 2000 & 2300 & 2300 & 1.19 \\
\hline 7 & $\mathrm{Nd}(\mathrm{OTf})_{3}$ & PPD & 100:1:5 & 26 & 89 & 3700 & 4200 & 3200 & 1.19 \\
\hline 8 & $\mathrm{Nd}(\mathrm{OTf})_{3}$ & PPD & 200:1:5 & 96 & 81 & 6800 & 7000 & 3700 & 1.35 \\
\hline 9 & $\mathrm{Nd}(\mathrm{OTf})_{3}$ & TMM & $60: 1: 5$ & 18 & 91 & 2400 & 2300 & 1600 & 1.34 \\
\hline 10 & $\mathrm{Nd}(\mathrm{OTf})_{3}$ & TMM & $120: 1: 5$ & 48 & 66 & 3400 & 2600 & 1900 & 1.34 \\
\hline 11 & $\mathrm{Nd}(\mathrm{OTf})_{3}$ & TMM & $240: 1: 5$ & 96 & 60 & 6000 & 5700 & 3800 & 1.36 \\
\hline 12 & MSA & PPD & $20: 1: 5$ & 20 & 81 & 750 & 800 & 1300 & 1.58 \\
\hline 13 & MSA & PPD & $30: 1: 5$ & 20 & 91 & 1200 & 1000 & 1000 & 1.57 \\
\hline 14 & MSA & PPD & 100:1:5 & 50 & 94 & 3900 & 2100 & 1700 & 1.30 \\
\hline 15 & MSA & PPD & 200:1:5 & 50 & 42 & 3500 & 2300 & 500 & 1.38 \\
\hline
\end{tabular}

${ }^{a}$ All reactions were performed in bulk at $60{ }^{\circ} \mathrm{C}$ (refer to the Experimental Section). ${ }^{\mathrm{b}}$ The reaction time was not necessarily optimized. ${ }^{\mathrm{c}}$ Monomer conversion determined by ${ }^{1} \mathrm{H}$ NMR analysis of the crude reaction mixture (refer to the Experimental Section). ${ }^{\mathrm{d}}$ Theoretical molar mass value calculated from the relation: $\left[\mathrm{MLA}^{\mathrm{Be}}\right]_{0} /[\text { Initiator }]_{0} \times$ conv.MLABe $\times M_{\mathrm{MLABe}}+M_{\mathrm{Initiator}}$, with $M_{\mathrm{MLABe}}=206 \mathrm{~g} \cdot \mathrm{mol}^{-1}, M_{\mathrm{PPD}}$ $=76 \mathrm{~g} \cdot \mathrm{mol}^{-1}$, and $M_{\mathrm{TMM}}=106 \mathrm{~g} \cdot \mathrm{mol}^{-1}$. ${ }^{\mathrm{e}}$ Experimental molar mass value determined by ${ }^{1} \mathrm{H} \mathrm{NMR}$ analysis of the isolated polymer, from the relative intensities of the resonances of the main chain methane or methylene hydrogens to the methylene hydrogens of the initiator (refer to the Experimental Section). ${ }^{\mathrm{f}}$ Number average molar mass value determined by SEC in THF at $30{ }^{\circ} \mathrm{C} v s$. polystyrene standards (uncorrected values, refer to the Experimental Section). ${ }^{\mathrm{g}}$ Dispersity value $(\mathrm{Mw} / \mathrm{Mn})$ determined by SEC in THF at $30^{\circ} \mathrm{C}$.

The metallic triflates $\mathrm{Nd}(\mathrm{OTf})_{3}$ and $\mathrm{Bi}(\mathrm{OTf})_{3}$ were both found active catalysts in the ROP of $\mathrm{MLA}^{\mathrm{Be}}$ initiated by 1,3-propane diol (Table 1, entries 1-8). Under the same conditions, the bismuth catalyst was more active than the neodymium, converting 100 equiv. of the lactone within $2 \mathrm{~h}$ as opposed to more than $26 \mathrm{~h}$ required with the rare earth metal 
system (Table 1, entries 2 vs. 7). However, the control of the polymerization was significantly better using the $\mathrm{Nd}(\mathrm{OTf})_{3} / \mathrm{PPD}$ catalytic system, as evidenced by the close match of the anticipated molar mass values $\left(M_{\mathrm{n}, \text { theo }}\right)$ with the molar mass values determined from ${ }^{1} \mathrm{H}$ NMR analysis of the precipitated polymer $\left(M_{\mathrm{n}, \mathrm{NMR}}\right.$, refer to the Experimental Section; Figure $\left.\mathrm{S} 1\right)$, and by the slightly narrower dispersities measured by SEC analysis $\left(\bigoplus_{\mathrm{M}, \mathrm{Nd}(\mathrm{OTf}) 3}=1.2-1.3 v s\right.$. $\left.\bigoplus_{\mathrm{M}, \mathrm{Bi}(\mathrm{OTf}) 3}=1.3-1.4\right) .^{48}$ These dispersity values remained in the range of those obtained from the related ROP of MLA ${ }^{\mathrm{Be}}$ promoted by $\mathrm{Al}(\mathrm{OTf})_{3} / \mathrm{BnOH}\left(\bigoplus_{\mathrm{M}}=1.2\right)^{35}$ or organic bases $\left(\bigoplus_{\mathrm{M}}=\right.$ 1.1-1.4). ${ }^{30}$ Furthermore, these values indicated the occurrence of few undesirable transesterification side reactions (reshuffling (intermolecular) and backbiting (intramolecular), and chain transfer reactions) often observed in ROP of cyclic esters, ${ }^{49}$ and/or a faster rate of initiation with respect to propagation. Furthermore, the molar mass value of the thus formed PMLA $^{\mathrm{Be}}$ increased linearly with $\left(\left[\mathrm{MLA}^{\mathrm{Be}}\right]_{0} \mathrm{x}\right.$ conv. MLABe $) /[\mathrm{PPD}]_{0}$ ratio, as depicted Figure 1. All these data are indicative of a living polymerization. The similar ROP of MLA ${ }^{\mathrm{Be}}$ catalyzed by $\mathrm{Nd}(\mathrm{OTf})_{3}$ in presence of a triol $(\mathrm{TMM})$ afforded the corresponding $\mathrm{PMLA}^{\mathrm{Be}}$ triol, with a similar control of the polymerization in terms of $M_{\mathrm{n}, \text { theo }} / M_{\mathrm{n}, \mathrm{NMR}}$ agreement and narrow dispersity (Table 1, entries 9-11). All these results allowed establishing the proof of this concept towards the synthesis of $\alpha, \omega$-hydroxy telechelic PMLA ${ }^{\mathrm{Be}}$ s from metallic triflates and hydroxylated initiators. 


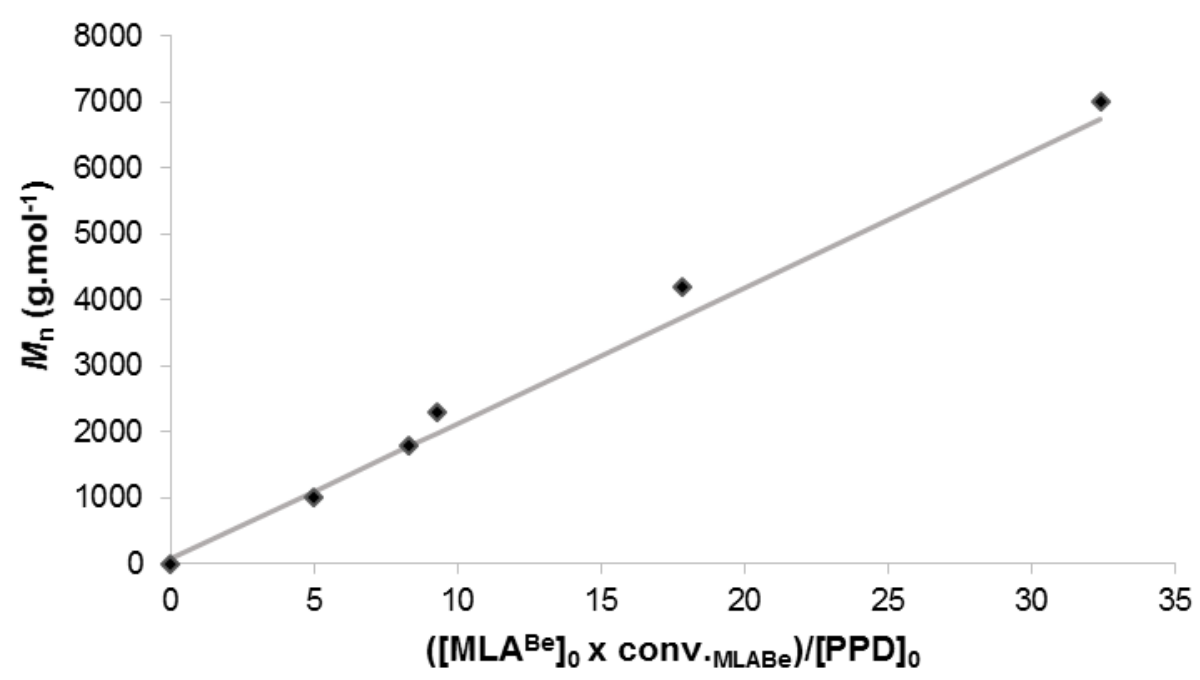

Figure 1. Variation of $M_{\mathrm{n}, \mathrm{NMR}}(\diamond)$ and $M_{\mathrm{n} \text {,theo }}$ (solid line) values of PMLA ${ }^{\mathrm{Be}}$, produced in the presence of $\mathrm{Nd}(\mathrm{OTf})_{3} / \mathrm{PPD}$, as a function of $\left(\left[\mathrm{MLA}^{\mathrm{Be}}\right]_{0} \times\right.$ conv.MLABe $) /[\mathrm{PPD}]_{0}$ (Table 1 , entries 4-8).

As initially investigated by Pohl and co-workers, ${ }^{43}$ the protic acid catalyzed ROP of $\beta$-butyrolactone (BL) mediated by triflic acid (HOTf) $)^{43-45}$ or methane sulfonic acid (MSA) ${ }^{45}$ in presence of an alcohol (ROH), afforded $\alpha$-hydroxy, $\omega$-alkoxy telechelic PHBs. The polymerizations of $\mathrm{BL}$ proceeded at $30-35^{\circ} \mathrm{C}$ in an aprotic solvent $\left(\mathrm{C}_{6} \mathrm{D}_{6}-\mathrm{NMR}\right.$ tube experiments, or toluene) with methanol or $n$-pentanol, via selective oxygen-acyl bond cleavage, along with formation of a minor amount of macrocycles while crotonate chain-ends were observed at higher temperatures. In these ROPs of BL, HOTf showed a better activity and selectivity compared to MSA which led to some cyclisation and crotonisation reactions. Also, the use of a dihydroxylated initiator (1,4-butane diol) with HOTf catalyst gave the corresponding PHB diol. ${ }^{45}$ In comparison to these acid catalyzed ROPs of BL, ROP of the related $\mathrm{MLA}^{\mathrm{Be}} \beta$-lactone mediated by HOTf/PPD at $60^{\circ} \mathrm{C}$ did not enable the synthesis of PMLA $^{\mathrm{Be}}$ diol. Indeed, a white precipitate, possibly arising from some transesterification reactions, was then recovered from which no product besides some fumaric acid could be 
identified. On the other hand, PPD effectively initiated the ROP of MLA ${ }^{\text {Be }}$ catalyzed by MSA under the same operating conditions (Table 1, entries 12-15). The polymerization proceeded also with oxygen-acyl bond cleavage leading to $\mathrm{PMLA}^{\mathrm{Be}}$ diol as characterized by ${ }^{1} \mathrm{H}$ NMR analysis (vide infra, Figure S2). However, the polymers failed to show a good correlation for their molar mass between the theoretical values $\left(M_{\mathrm{n}, \text { theo }}\right)$ and the experimental ones as determined by ${ }^{1} \mathrm{H}$ NMR $\left(M_{\mathrm{n}, \mathrm{NMR}}\right.$, Table 1 ; vide infra). Thus, as opposed to the ROP of BL, neither HOTf nor MSA efficiently promoted the ROP of MLA ${ }^{\mathrm{Be}}$ initiated by PPD at $60^{\circ} \mathrm{C}$. The benzylester substituent of MLA ${ }^{\mathrm{Be}}$ thus altered the reactivity of the $\beta$-lactone as compared to the methyl group of $\mathrm{BL}$, most likely as the result of its electronic contribution. Thus, $\mathrm{Nd}(\mathrm{OTF})_{3} / \mathrm{PPD}$ and $\mathrm{Nd}(\mathrm{OTF})_{3} / \mathrm{TMM}$ revealed as the most effective catalytic systems for the controlled ROP of MLA ${ }^{\mathrm{Be}}$ towards hydroxyl end-capped $\mathrm{PMLA}^{\mathrm{Be}} \mathrm{s}$, as further evidenced by spectroscopic characterizations (vide infra). This direct strategy towards the synthesis of PMLA $^{\mathrm{Be}}$ diol and triol compares favorably well with the previously reported formation of PMLA $^{\mathrm{Be}}$ diol through the chemical modification of a pre-isolated $\alpha$-hydroxy, $\omega$-carboxylic acid PMLA ${ }^{\mathrm{Be}}$ sample. Indeed, this prior experiment reported that in presence of an excess of borane-tetrahydrofuran adduct $\left(\mathrm{BH}_{3}\right.$.THF; 3.5 equiv.) at $0{ }^{\circ} \mathrm{C}$ in anhydrous $\mathrm{THF}$ over $5 \mathrm{~h}$, the reduction of the carboxylic acid end-group into a hydroxyl one proceeded to

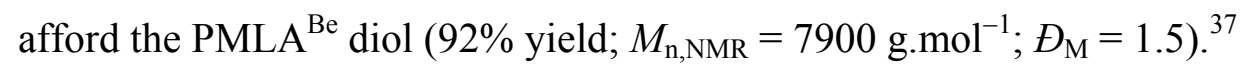

Characterization of the PMLA ${ }^{\mathbf{B e}}$ s. ${ }^{1} \mathrm{H}$ NMR analysis of the precipitated $\mathrm{PMLA}^{\mathrm{Be}}-n$ ols enabled to verify the presence of $\mathrm{MLA}^{\mathrm{Be}}$ repeating units as well as to confirm the nature of the chain-end groups. The typical spectrum of a low molar mass PMLA $^{\text {Be }}$ diol is illustrated Figure 2 with the sample isolated from the ROP of $\mathrm{MLA}^{\mathrm{Be}}$ promoted by $\mathrm{Nd}(\mathrm{OTf})_{3}$ in the presence of 1,3 propanediol as initiator (Table 1, entry 1). Besides the expected ester backbone signals of the methine and methylene hydrogens observed in a 1:2 ratio $(\delta=5.50$ ppm $\left(\mathrm{CH}_{2} \mathrm{CH}\left(\mathrm{CO}_{2} \mathrm{Be}\right) \mathrm{O}\right), 2.92 \mathrm{ppm}\left(\mathrm{CHCH}_{2} \mathrm{C}(\mathrm{O}) \mathrm{O}\right)$, as well as the signals of the benzyloxy 
pending substituent $\left(\delta=7.30,5.12 \mathrm{ppm}\left(\mathrm{OCH}\left(\mathrm{CO}_{2} \mathrm{CH}_{2} \mathrm{C}_{6} H_{5}\right) \mathrm{CH}_{2} \mathrm{C}(\mathrm{O})\right)\right.$, the central trimethylene moiety $\left(\delta=4.18,1.80 \mathrm{ppm}\left(\mathrm{OCH}_{2} \mathrm{CH}_{2} \mathrm{CH}_{2} \mathrm{O}\right)\right)$, and the terminal hydroxyl $(\delta=3.63 \mathrm{ppm})$ resonances were also observed (Figure 2$)$. The signals of the chain-end groups and especially of the trimethylene central sequence being well resolved, this allowed a fairly reliable integration of the resonances as illustrated in Figure 2. Consequently, evaluation of the PMLA ${ }^{\mathrm{Be}} \mathrm{s}$ molar mass $\left(M_{\mathrm{n}, \mathrm{NMR}}\right)$ from the relative intensity of the chain-end and of the alcohol segment vs. the main chain signals, gave values in good agreement with the ones calculated from the monomer conversion and the initial amount of $\mathrm{MLA}^{\mathrm{Be}}$ and initiator $\left(M_{\mathrm{n}, \text { theo }}\right)$, as reported Table 1 . The corresponding ${ }^{13} \mathrm{C}\left\{{ }^{1} \mathrm{H}\right\}$ NMR spectrum also evidenced $\mathrm{MLA}^{\mathrm{Be}}$ units $^{30}$ along with the alcohol segment $\left(\delta=65.4,38.6 \mathrm{ppm}\left(\mathrm{OCH}_{2} \mathrm{CH}_{2} \mathrm{CH}_{2} \mathrm{O}\right)\right)$ (Figure 3). The same ${ }^{1} \mathrm{H}$ and ${ }^{13} \mathrm{C}\left\{{ }^{1} \mathrm{H}\right\}$ patterns were obtained in the spectra of PMLA ${ }^{\mathrm{Be}}$ diol and $\mathrm{PMLA}^{\mathrm{Be}}$ triol, similarly synthesized from $\mathrm{Bi}(\mathrm{OTf})_{3}, \mathrm{MSA} / \mathrm{PPD}$ and $\mathrm{Nd}(\mathrm{OTf})_{3} / \mathrm{TMM}$, respectively. The only distinctive feature was the relative intensity of the ${ }^{1} \mathrm{H}$ NMR signals corresponding to the hydrogens of the central alcohol moiety which differed from PPD (vide supra $)$ to $\left.\mathrm{TMM}\left(\delta=4.06 \mathrm{ppm}, 6 \mathrm{H},\left(\mathrm{OCH}_{2} \mathrm{CH}\left(\mathrm{CH}_{2} \mathrm{O}\right)_{2}\right)\right), 2.05 \mathrm{ppm}, 1 \mathrm{H},\left(\mathrm{OCH}_{2} \mathrm{CH}\left(\mathrm{CH}_{2} \mathrm{O}\right)_{2}\right)\right)$ (Figures 4,5 ). Also, the ${ }^{1} \mathrm{H}$ NMR spectra of PMLA ${ }^{\mathrm{Be}}$ diols synthesized using either Bi(OTf $)_{3}$ or MSA catalyst with PPD, showed the expected integral value for the methylene signal of the main chain $\left(\left(\mathrm{CHCH}_{2} \mathrm{C}(\mathrm{O}) \mathrm{O}\right), \delta=2.92 \mathrm{ppm}\right)$, whereas the methine and methylene signals (( $\left.\mathrm{CH}\left(\mathrm{CO}_{2} \mathrm{CH}_{2} \mathrm{Ph}\right) \mathrm{CH}_{2} \mathrm{C}(\mathrm{O}) \mathrm{O}\right), \delta=5.50,5.12 \mathrm{ppm}$, respectively) failed to provide the corresponding expected integral values (2:1:2 ratio, respectively; Figures S1-S2). This incoherence suggested the presence of (an) unidentified side species and further highlighted the poor control in the case of the ROP mediated by these two catalyst systems.

NMR analyses also provided valuable information about the mechanism taking place during the polymerization of $\mathrm{MLA}^{\mathrm{Be}}$ promoted by $\mathrm{Nd}(\mathrm{OTf})_{3}$. First, the alcohol used as initiator was found to be quantitatively incorporated into the PMLA $^{\text {Be }}$ chains as a central 
linkage. Also, the relative intensity ratio between the PPD or TMM (signals $a, b$ ) and the terminal hydroxyl (signal $g$ ) signals supported an efficient initiation with all the polymer chains being initiated by the alcohol. Furthermore, these observations evidenced the selective ring-opening of $\mathrm{MLA}^{\mathrm{Be}}$ occurring with oxygen-acyl bond cleavage, thereby generating a propagating hydroxyl chain-end, and ultimately affording a hydroxyl end-capping group. Indeed, as a four membered-ring $\beta$-lactone, $\mathrm{MLA}^{\mathrm{Be}}$ may also be ring-opened with oxygen-alkyl bond rupture to give propagating carboxylic acid chain resulting in $-\mathrm{COOH}(\delta=$ ca. $10.8 \mathrm{ppm}$ ) end-functionalized PMLA ${ }^{\mathrm{Be}},{ }^{18-20}$ a chain-end yet not observed in the present study. Finally, $\mathrm{MLA}^{\mathrm{Be}}$ is also prone to undergo crotonisation reactions upon elimination of $\mathrm{H}_{2} \mathrm{O}$, leading to an acrylic non-propagating chain end. ${ }^{18-20}$ Such $-\mathrm{C}(\mathrm{O}) \mathrm{CH}=\mathrm{CH}\left(\mathrm{CO}_{2} \mathrm{CH}_{2} \mathrm{Ph}\right)$ moieties $\left(\delta_{\mathrm{CH}=\mathrm{CH}}=c a .5 .70-5.80,6.80-7.00\right.$ ppm $)$ were not observed in the NMR nor in mass (vide infra) spectra of the recovered polyester samples. These observations are in agreement with the narrow dispersities measured by SEC (vide supra). Based on these findings, the ROPs of $\mathrm{MLA}^{\mathrm{Be}}$ promoted by $\mathrm{Nd}(\mathrm{OTf})_{3} / \mathrm{PPD}, \mathrm{TMM}$ were thus further demonstrated to proceed with a good control and high selectivity, whereas in the case of $\mathrm{Bi}(\mathrm{OTf})_{3}$ and MSA catalyzed ROPs in presence of PPD as initiator, the overall control was poorer.

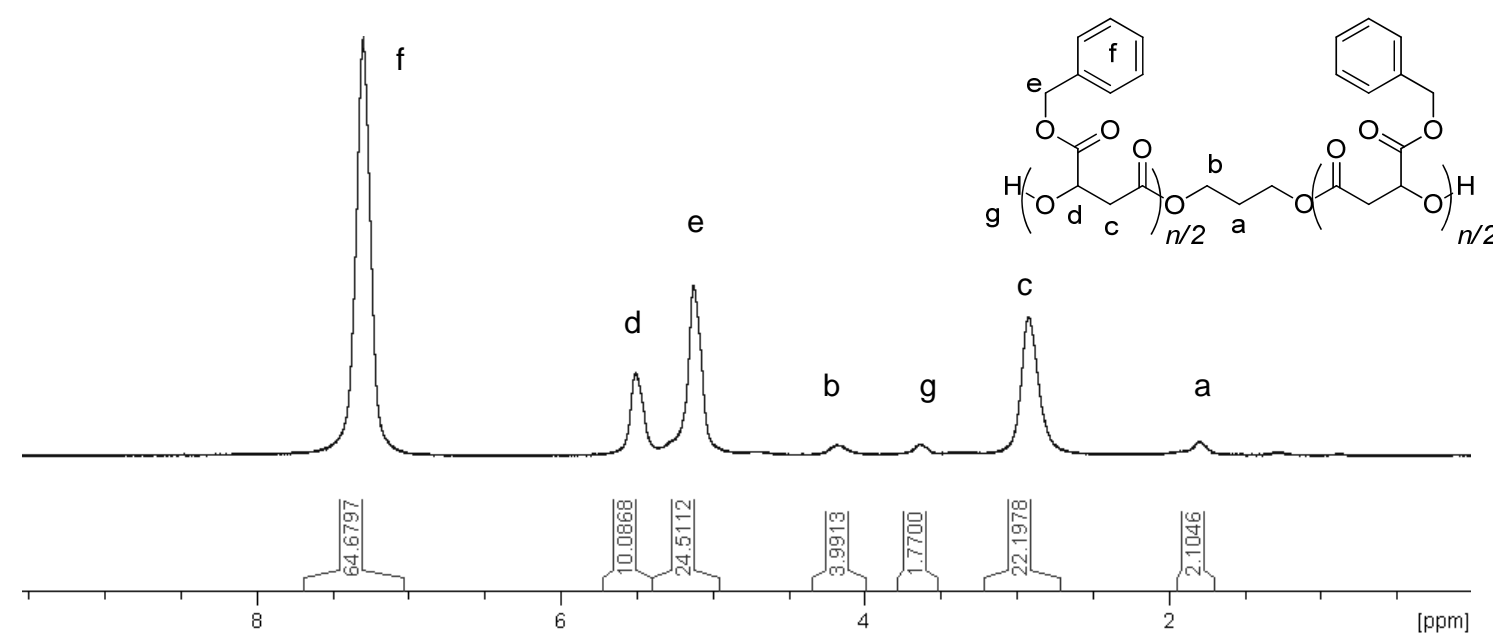


Figure 2. ${ }^{1} \mathrm{H}$ NMR spectrum $\left(\mathrm{CDCl}_{3}, 500 \mathrm{MHz}, 25^{\circ} \mathrm{C}\right)$ of a $\mathrm{PMLA}^{\mathrm{Be}}$ diol synthesized by ROP of $\mathrm{MLA}^{\mathrm{Be}}$ catalyzed by $\mathrm{Nd}(\mathrm{OTf})_{3}$ in the presence of 5 equiv. of 1,3 propanediol as initiator (Table 1, entry 6).

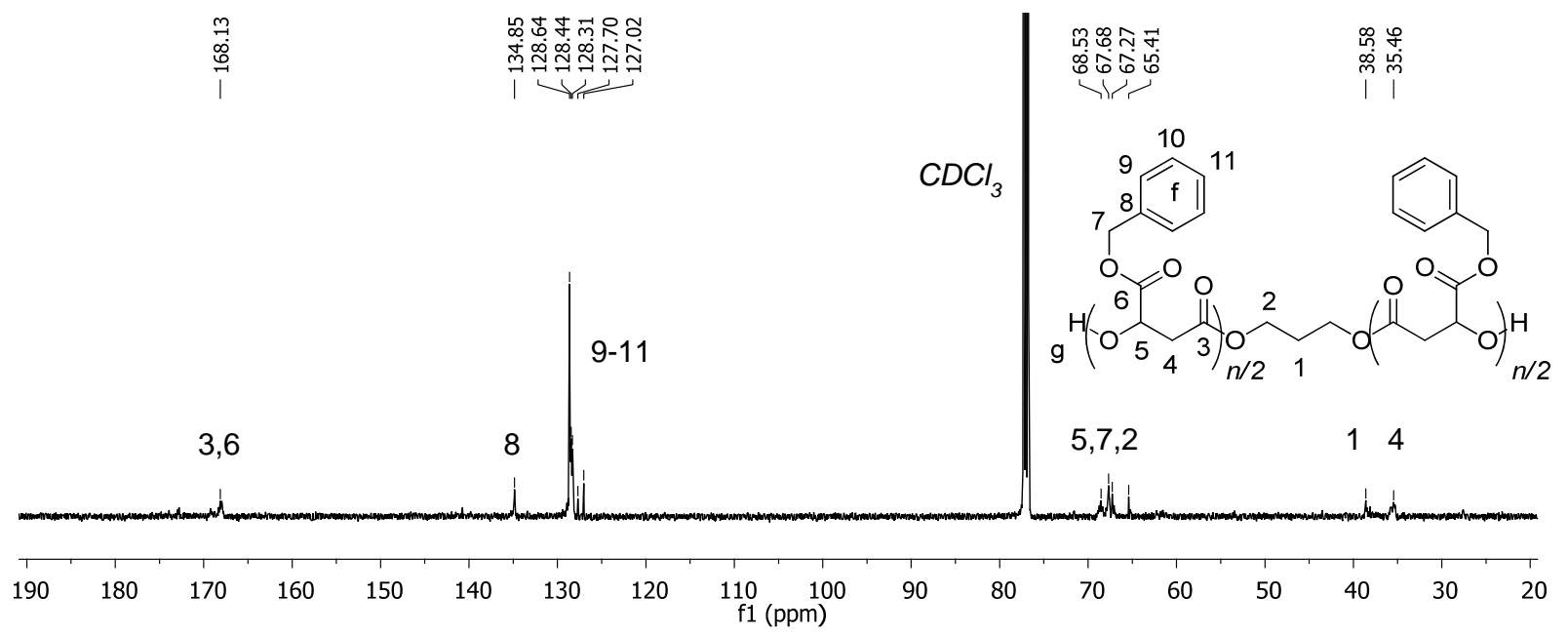

Figure 3. ${ }^{13} \mathrm{C}\left\{{ }^{1} \mathrm{H}\right\}$ NMR spectrum $\left(\mathrm{CDCl}_{3}, 125 \mathrm{MHz}, 25^{\circ} \mathrm{C}\right)$ of a $\mathrm{PMLA}^{\mathrm{Be}}$ diol synthesized by $\mathrm{ROP}$ of $\mathrm{MLA}^{\mathrm{Be}}$ catalyzed by $\mathrm{Nd}(\mathrm{OTf})_{3}$ in presence of 5 equiv. of 1,3 propanediol as initiator (Table 1, entry 6).

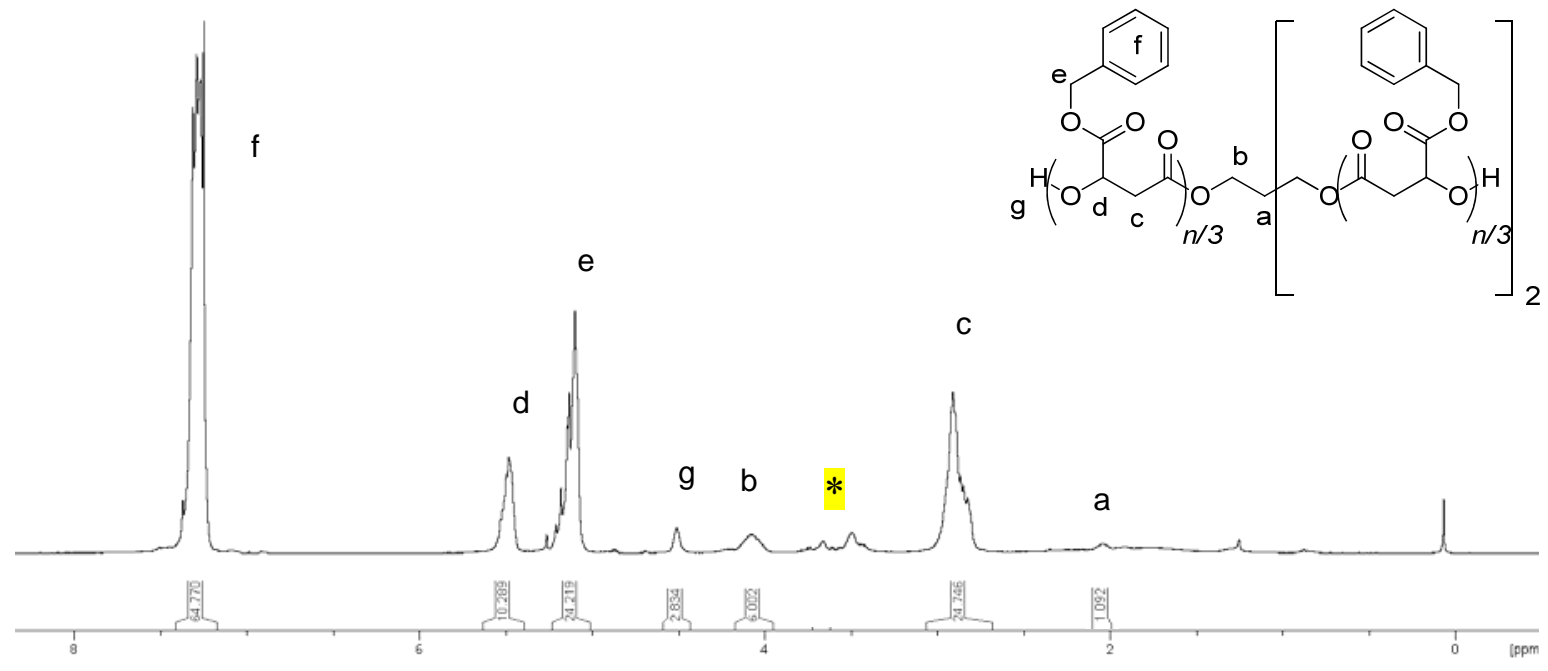

Figure 4. ${ }^{1} \mathrm{H}$ NMR spectrum $\left(\mathrm{CDCl}_{3}, 500 \mathrm{MHz}, 25^{\circ} \mathrm{C}\right)$ of a $\mathrm{PMLA}^{\mathrm{Be}}$ triol synthesized by ROP of rac-MLA ${ }^{\mathrm{Be}}$ catalyzed by $\mathrm{Nd}(\mathrm{OTf})_{3}$ in presence of 5 equiv. of 2-hydroxymethyl-1,3propanediol as initiator (* marker stands for residual MLA ${ }^{\mathrm{Be}}$; Table 1, entry 10). 


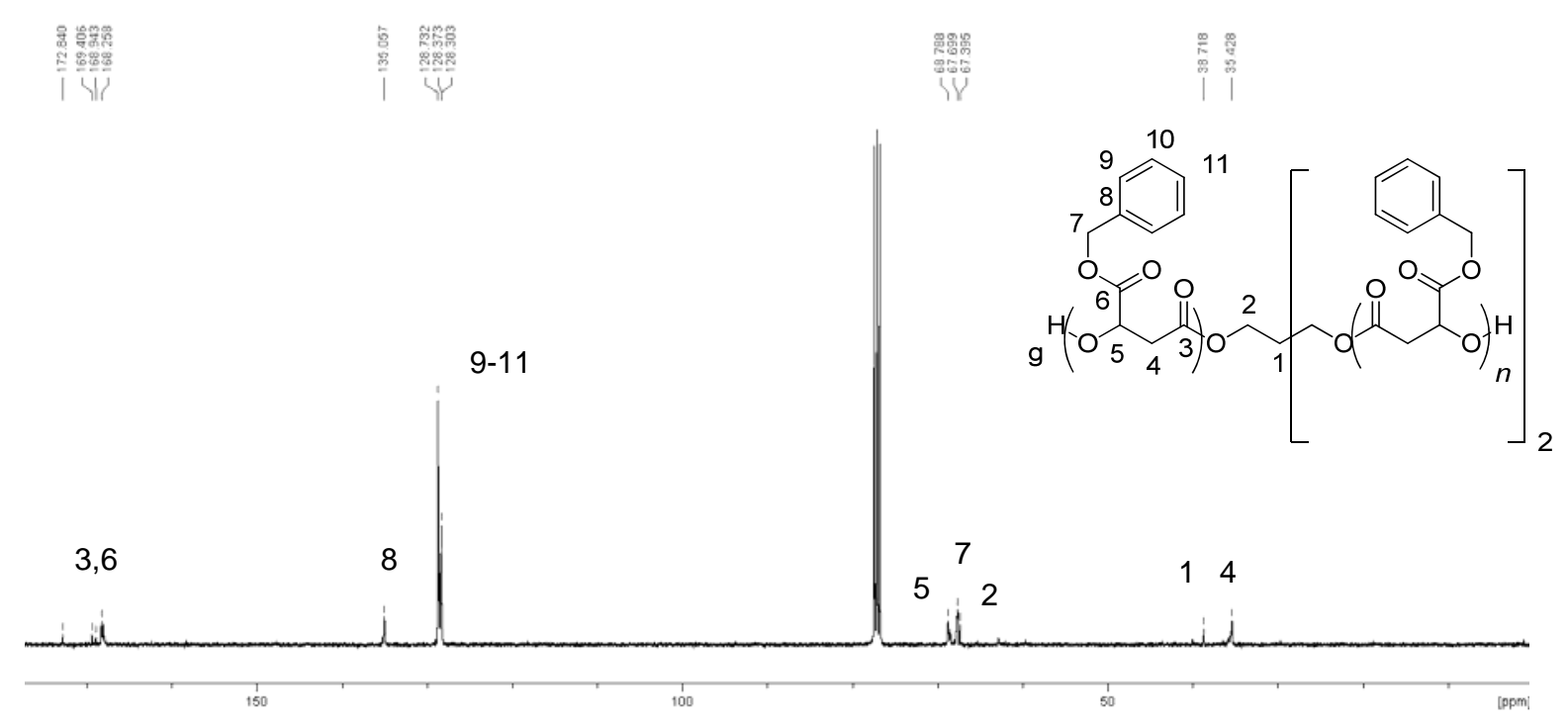

Figure 5. ${ }^{13} \mathrm{C}\left\{{ }^{1} \mathrm{H}\right\}$ NMR spectrum $\left(\mathrm{CDCl}_{3}, 125 \mathrm{MHz}, 25{ }^{\circ} \mathrm{C}\right)$ of a $\mathrm{PMLA}^{\mathrm{Be}}$ triol synthesized by $\mathrm{ROP}$ of $r a c-\mathrm{MLA}^{\mathrm{Be}}$ catalyzed by $\mathrm{Nd}(\mathrm{OTf})_{3}$ in presence of 5 equiv. of 2-hydroxymethyl1,3-propanediol as initiator (Table 1, entry 10).

Formation of hydroxy telechelic PMLA ${ }^{\mathrm{Be}} \mathrm{s}$ was further supported by MALDI-ToF mass spectrometry (MS) analyses. The spectrum recorded from a low molar mass sample prepared from the $\mathrm{Nd}(\mathrm{OTf})_{3} / \mathrm{PPD}$ catalytic system and using ditranol as a matrix, revealed a very major population of $\alpha, \omega$-dihydroxy telechelic PMLA $^{\mathrm{Be}}$ featuring a repeating unit of 206 g.mol ${ }^{-1}\left(M_{\text {MLABe }}\right)$ (Figure 6). This was unequivocally confirmed by the close match with the isotopic simulation of a PMLA ${ }^{\mathrm{Be}}$ ionized by $\mathrm{Na}^{+}$and end-capped by hydroxyl groups, that is $\left[\mathrm{CH}_{2}\left\{\mathrm{CH}_{2} \mathrm{O}\left(\mathrm{C}(\mathrm{O}) \mathrm{CH}_{2} \mathrm{CH}\left(\mathrm{C}(\mathrm{O}) \mathrm{OCH}_{2} \mathrm{Ph}\right) \mathrm{O}\right)_{n} \mathrm{H}\right\}_{2}\right] \cdot \mathrm{Na}^{+}$with e.g. $m / z=2160.6$ g.mol ${ }^{-1}$ (vs. $m / z$ (experimental) $=2160.2 \mathrm{~g} \cdot \mathrm{mol}^{-1}$ ) for $2 n=10$ (zoom of Figure 6). Similarly, the MALDI-ToF MS of a low molar mass PMLA ${ }^{\text {Be }}$ sample synthesized from the $\mathrm{Nd}(\mathrm{OTf})_{3} / \mathrm{TMM}$ catalytic system also using ditranol as a matrix, displayed a major population with a repeating unit of 206 g.mol ${ }^{-1}$ corresponding to $\alpha, \omega$-trihydroxy telechelic $\mathrm{PMLA}^{\mathrm{Be}}$ ionized by $\mathrm{Na}^{+}$, that is $\left[\mathrm{CH}\left\{\mathrm{CH}_{2} \mathrm{O}\left(\mathrm{C}(\mathrm{O}) \mathrm{CH}_{2} \mathrm{CH}\left(\mathrm{C}(\mathrm{O}) \mathrm{OCH} \mathrm{CH}_{2} \mathrm{Ph}\right) \mathrm{O}\right)_{n} \mathrm{H}\right\}_{3}\right] \cdot \mathrm{Na}^{+}$with e.g. $\mathrm{m} / z=2602.8 \mathrm{~g} \cdot \mathrm{mol}^{-1}$ (vs. $\mathrm{m} / z$ (experimental) $=2601.9$ g. $\mathrm{mol}^{-1}$ ) for $3 n=12$, as confirmed by the isotopic simulation (Figure 7). 
The minor envelope observed in this latter MS spectrum was assigned to the same macromolecules ionized by $\mathrm{K}^{+}$. Noteworthy, these MALDI-ToF MS analyses showed no indication of carboxylic acid or crotonate chain-end groups, or any other species, in agreement with NMR analyses (vide supra).

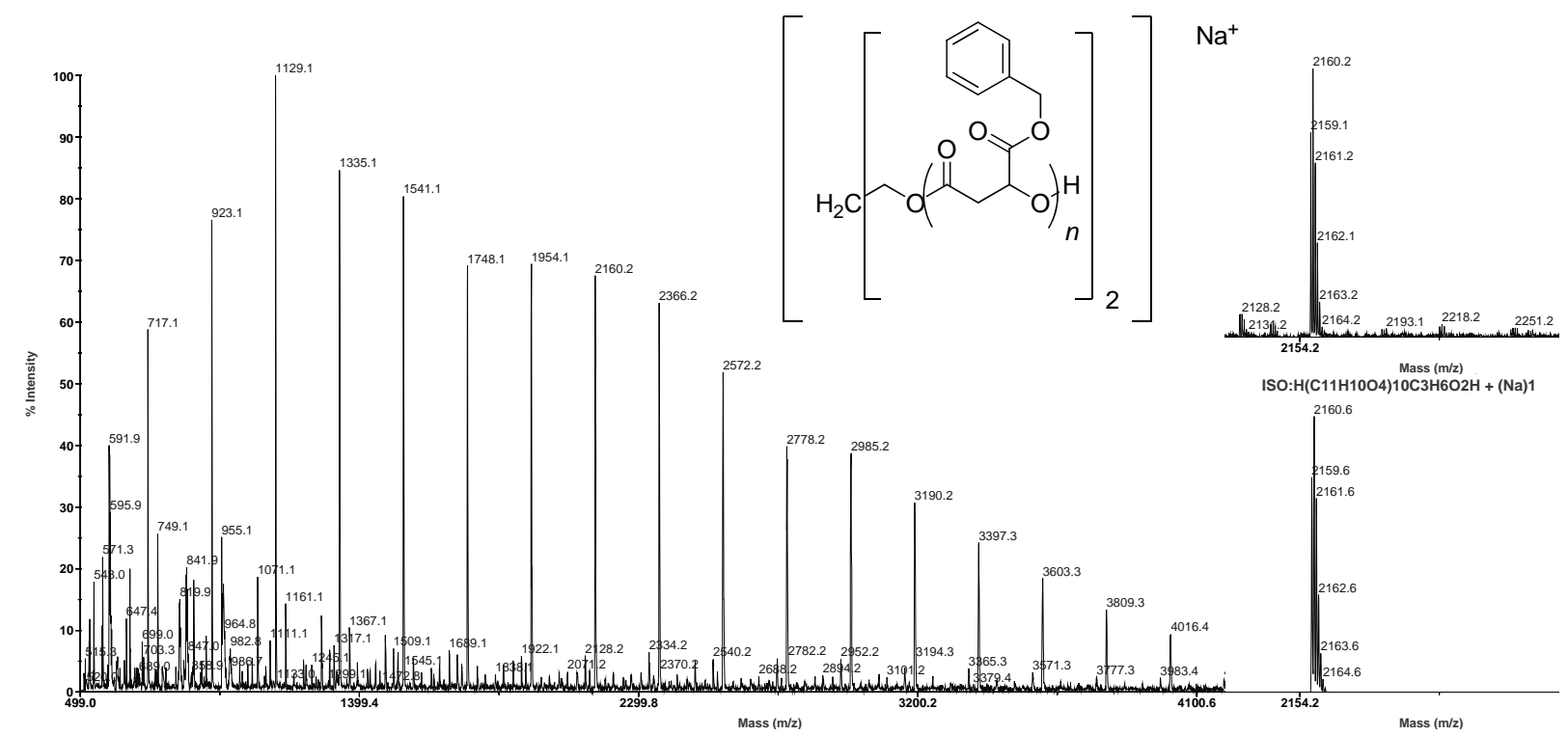

Figure 6. MALDI-ToF MS spectrum of a PMLA ${ }^{\mathrm{Be}}$ diol synthesized by ROP of MLA ${ }^{\mathrm{Be}}$ catalyzed by $\mathrm{Nd}(\mathrm{OTf})_{3}$ in presence of 5 equiv. of 1,3 propanediol as initiator, using ditranol as a matrix (Table 1, entry 4). The left zooms correspond to the recorded (top) and the simulated (bottom) alike region. 


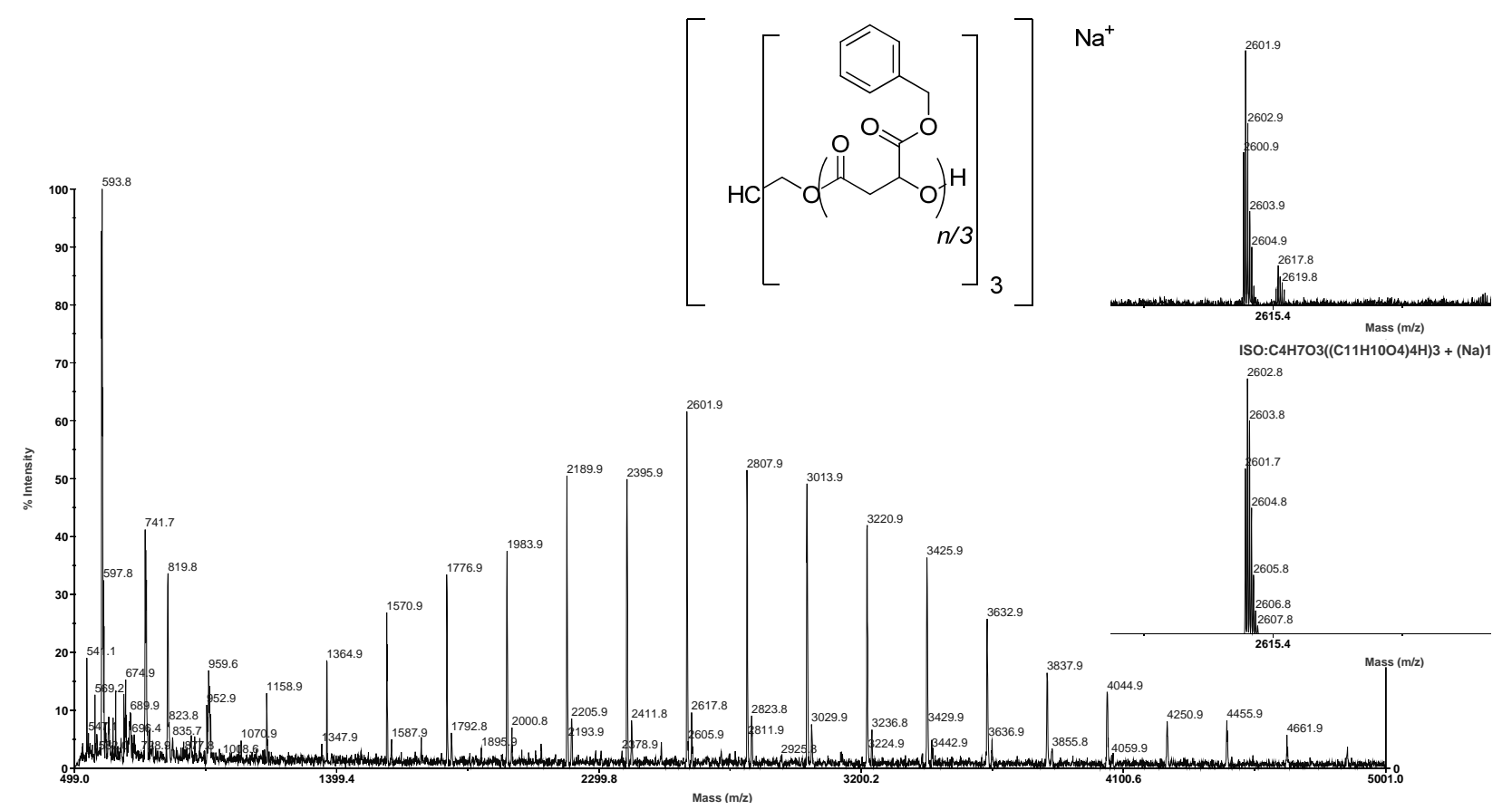

Figure 7. MALDI-ToF MS spectrum of a PMLA ${ }^{\mathrm{Be}}$ triol synthesized by the ROP of $\mathrm{MLA}^{\mathrm{Be}}$ catalyzed by $\mathrm{Nd}(\mathrm{OTf})_{3}$ in presence of 5 equiv. of 2-hydroxymethyl-1,3-propanediol as initiator, using ditranol as a matrix (Table 1, entry 8). The left zooms correspond to the recorded (top) and the simulated (bottom) alike region.

\section{Conclusion}

Catalytic systems composed of $\mathrm{Nd}(\mathrm{OTf})_{3}$ catalyst in the presence of hydroxyl-group containing compounds such as PPD or TMP as initiator, were found to promote the controlled ROP of benzyl $\beta$-malolactonate under mild conditions (i.e. in the absence of a solvent at $\left.60{ }^{\circ} \mathrm{C}\right)$. The ring-opening of $\mathrm{MLA}^{\mathrm{Be}}$ proceeds through the selective oxygen-acyl bond cleavage without undesirable side reactions such as inter- or intra-molecular transesterification reactions or crotonisation, as evidenced by ${ }^{1} \mathrm{H}$ and ${ }^{13} \mathrm{C}\left\{{ }^{1} \mathrm{H}\right\} \mathrm{NMR}$ and MALDI-ToF mass spectrometry analyses of the recovered polyesters. Both $\mathrm{Bi}(\mathrm{OTf})_{3}$ and methane sulfonic acid organo-catalyst also enabled the ROP of MLA ${ }^{\mathrm{Be}}$ in the presence of PPD, yet with a poor control. However, the alike triflic acid mediated ROP of MLA ${ }^{\mathrm{Be}}$ failed 
to afford the expected polymer, whereas HOTf was found active in the ROP of the related $\beta$-butyrolactone. ${ }^{45}$ This again highlights the significant differences previously reported ${ }^{38,39}$ between these two four membered-ring $\beta$-lactones - differing by the nature of the substituent in $\beta$-position of the lactone- both of which are yet challenging to ring-open polymerize. Direct synthesis (i.e. not by chemical modification of a preformed polymer) of PMLA ${ }^{\mathrm{Be}}$ diols and triols from a simple metal triflate and alcohol (both reactants being commercially available) further strengthens the growing interest in this monomer and its resulting polymer.

\section{Acknowledgements}

The authors gratefully thank the CNRS, the Region Bretagne (Ph.D. grant to C. G. J.) and the Fondation pour la Recherche Médicale (FRM "Chimie pour la Médecine”) (Ph.D. grant to G. B.) for supporting this research.

Electronic supplementary information (ESI) available: ${ }^{1} \mathrm{H}$ NMR spectra of PMLA ${ }^{\mathrm{Be}}$ diol synthesized from $\mathrm{Bi}(\mathrm{OTf})_{3} / \mathrm{PPD}$ and MSA/PPD catalytic systems. 


\section{Electronic Supplementary Information}

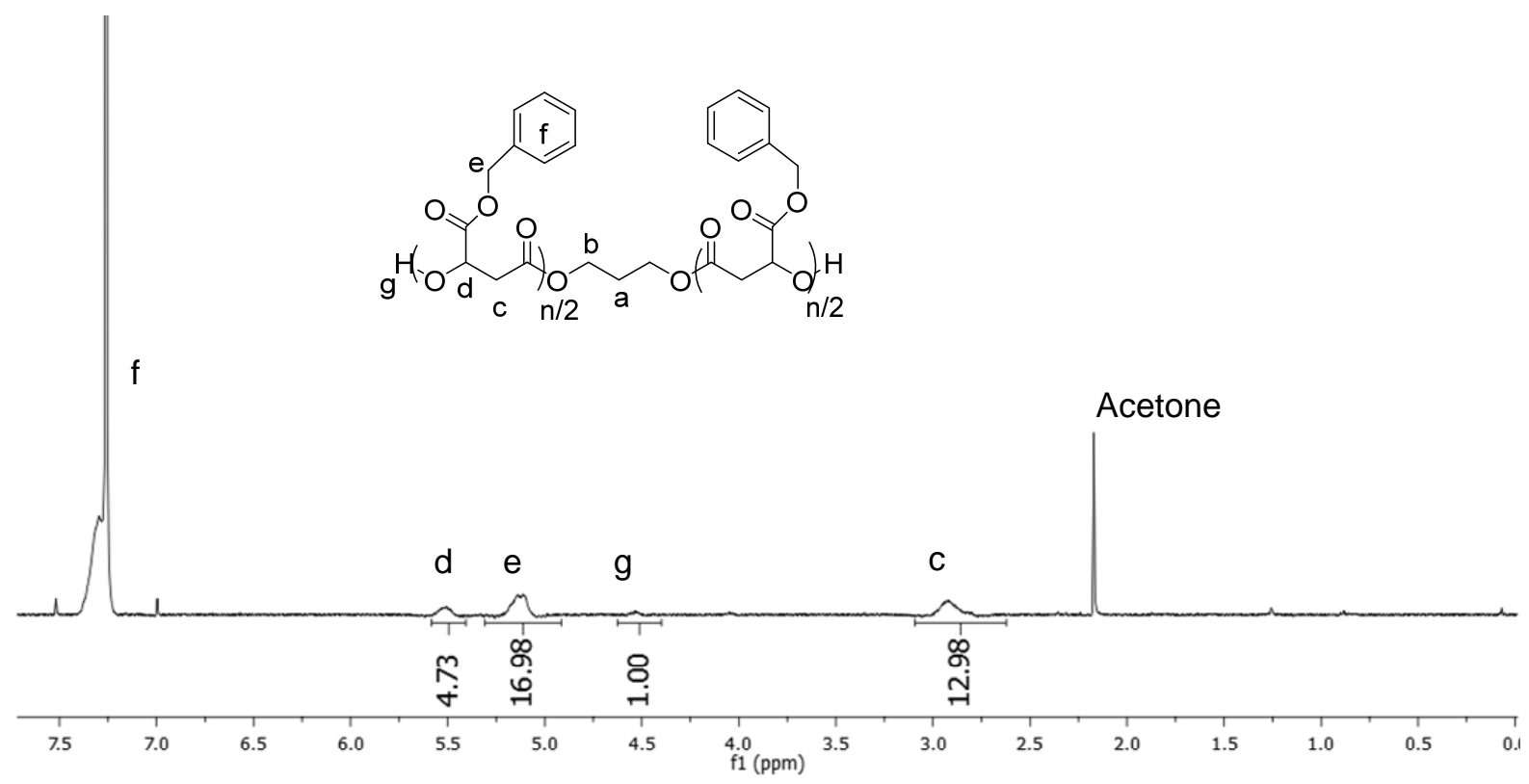

Figure S1. ${ }^{1} \mathrm{H}$ NMR spectrum $\left(\mathrm{CDCl}_{3}, 400 \mathrm{MHz}, 25^{\circ} \mathrm{C}\right)$ of a $\mathrm{PMLA}^{\mathrm{Be}}$ diol synthesized by ROP of MLA $^{\text {Be }}$ catalyzed by $\mathrm{Bi}(\mathrm{OTf})_{3}$ in presence of 5 equiv. of 1,3-propane diol as initiator (Table 1 , entry 2).

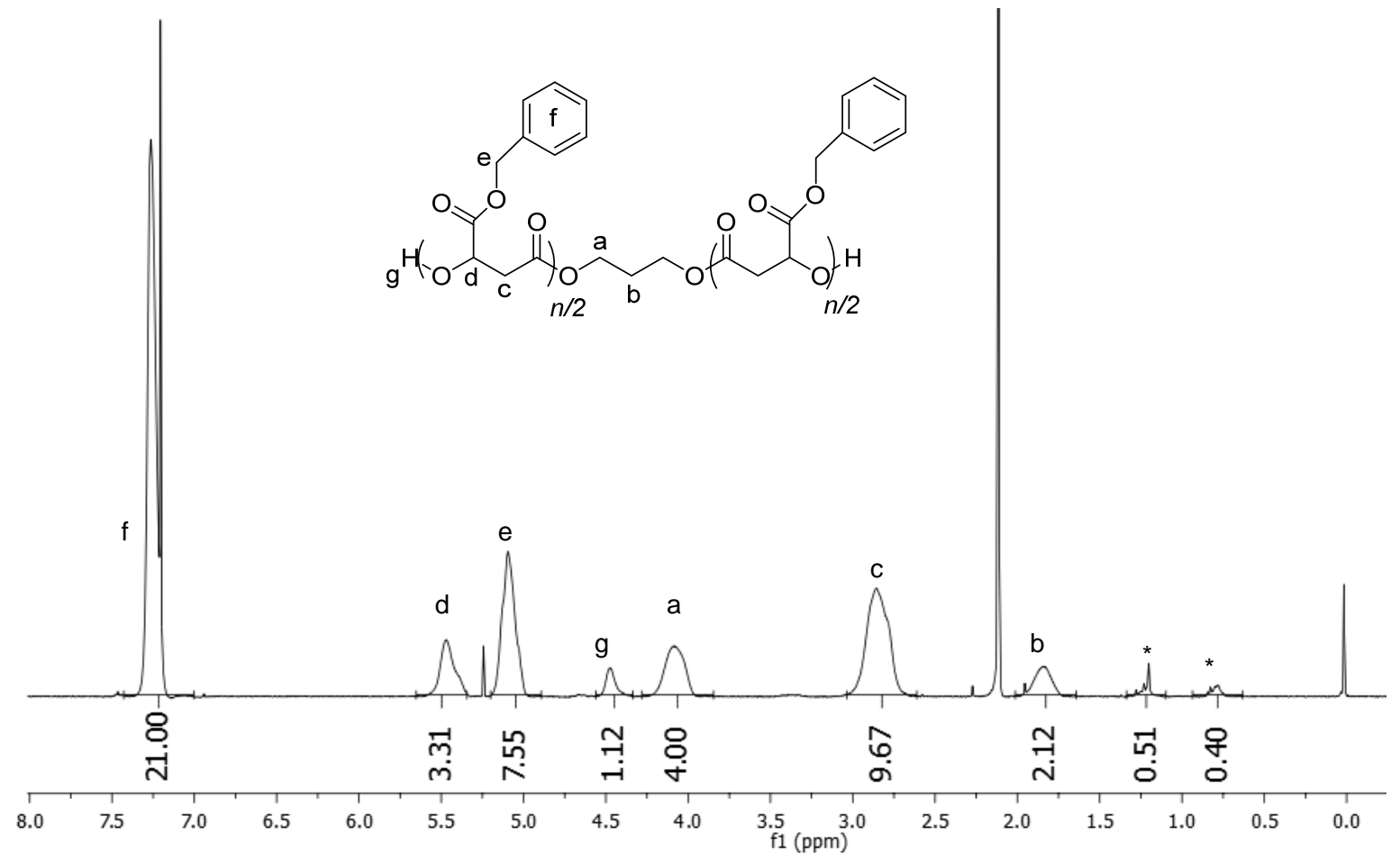

Figure S2. ${ }^{1} \mathrm{H}$ NMR spectrum $\left(\mathrm{CDCl}_{3}, 400 \mathrm{MHz}, 25^{\circ} \mathrm{C}\right)$ of a $\mathrm{PMLA}^{\mathrm{Be}}$ diol synthesized by ROP of MLA ${ }^{\text {Be }}$ catalyzed by MSA in presence of 5 equiv. of 1,3-propane diol as initiator (Table 1, entry 13). 


\section{References}

1 E. J. Goethals in Telechelic polymers: Synthesis and applications, ed. E. J. Goethals, CRC Press, Inc., Boca Raton, Florida, 1989.

2 M. A. Tasdelen, M. U. Kahveci, Y. Yagci Prog. Polym. Sci., 2011, 36, 455-567.

3 F. Lo Verso, C. N. Likos Polymer, 2008, 49, 1425-1434.

$4 \quad$ S. M. Guillaume Eur. Polym. J., 2013, 49, 769-779.

5 B. Laycock, P. Halley, S. Pratt, A. Werker and P. Lant, Prog. Polym. Sci., 2013, 38, $536-583$.

6 Taguchi, S.; Iwata, T.; Abe, H.; Doi, Y. Polym. Sci.: A Comprehensive Ref., 2012, 9, $157-182$.

7 X. Gao, J.-C. Chen, Q. Wu, G.-Q. Chen, Current Opinion in Biotechnology, 2011, 22, $768-774$.

8 Lu, J.; Tappel, R. C.; Nomura, C. T. J. Macromol. Sci. C: Polym. Rev., 2009, 49, $226-248$.

Lenz, R. W.; Marchessault, R. H. Biomacromolecules, 2005, 6, 1-8.

Chen, G.-Q. Chem. Soc. Rev., 2009, 38, 2434-2446.

Zinn, M.; Witholt, B.; Egli, T. Adv. Drug Deliv. Rev., 2001, 53, 5-21

Hazer, D. B.; Kilicay, E.; Hazer, B. Mater. Sci. and Eng. C, 2012, 32, 637-647.

Hazer, B. Energy and Power Engineering, 2010, 1, 31-38.

Coulembier, O.; Dubois, P. in Handbook of Ring-Opening Polymerization; Dubois, P., Coulembier, O., Raquez, J.-M. Eds.; Wiley-VCH, 2009; p 227-254.

Thomas, C. M. Chem. Soc. Rev. 2010, 39, 165-173.

J.-F. Carpentier, Macromol. Rapid Commun. 2010, 31, 1696-1705.

M. Vert Polym. Degrad. Stab., 1998, 59, 169v175.

O. Coulembier, P. Degée, J. L. Hedrick, P. Dubois Prog. Polym. Sci., 2006, 31, $723-747$.

R. J. Pounder, A. P. Dove Polym. Chem., 2010, 1, 260-271

C. G. Jaffredo, S. M. Guillaume Polym. Chem. 2014, 5, 4168-4194.

S. L. King, V. X. Truong, C. Kirchhoefer, A.Pitto-Barry, A. P. Dove Green Mat., 2014, 3, 107-122.

J. Y. Ljubimova, M. Fujita, A. V. Ljubimov, V. P. Torchilin, K. L. Black, E. Holler Nanomedicine, 2008, 3, 247-265. 
A. Aden, J. Bozell, J. Holladay, J. White, A. Manheim, in Top Value Added Chemicals From Biomass, Volume 1: Results of Screening for Potential Candidates from Sugars and Synthesis Gas, eds. T. Werpy, G. Petersen, Washington DC, 2004.

J. J. Bozell, G. R. Petersen Green Chem., 2010, 12, 539-554.

P. Loyer, S. Cammas-Marion, J. Drug Target., 2014, 22, 556-575.

C. G. Jaffredo, J.-F. Carpentier, S. M. Guillaume, Angew. Chem. Int. Ed. 2014, 53, 1-6.

S. Osanai, K. Nakamura Biomaterials, 2000, 21, 867-876.

S. Cammas-Marion, P. Guérin Macromol. Symp., 2000, 153, 167-186.

S. Cammas, I. Renard, V. Langlois, P. Guérin Polymer, 1996, 18, 4215-4220.

C. G. Jaffredo, J.-F. Carpentier, S. M. Guillaume Polym. Chem., 2013, 4, 3837-3850.

P. Guerin, J. Francillette, C. Braud, M. Vert Makromol. Chem., Macromol. Symp., 1986, 6, 305-314.

R. A. Gross, Y. Zhang, G. Konrad, R. W. Lenz, Macromolecules, 1988, 21, 2657-2668.

R. A. Gross, G. Konrad, Y. Zhang, R. W. Lenz, ACS Polym. Prepr., 1987, 28, 373-374.

O. Coulembier, P. Degée, C. Barbaud, P. Guérin, P. Dubois, Polym. Bull., 2004, 51, $365-372$.

M. Helou, G. Moriceau, Z. W. Huang, S. Cammas-Marion, S. M. Guillaume, Polym. Chem., 2011, 2, 840-850.

C. G. Jaffredo, J.-F. Carpentier, S. M. Guillaume, Macromolecules 2013, 46, $6765-6776$.

O. Coulembier, P. Degée, P. Dubois, Macromol. Chem. Phys. 2006, 207, 484v491.

C. G. Jaffredo, M. Schmid, I. del Rosal, T. Mevel, P. W. Roesky, L. Maron, S. M. Guillaume, Chem. Eur. J. , 2014, 44, 14387-14402.

S. M. Guillaume, L. Annunziata, L. Maron, C. Iftner, I. del Rosal, P. W. Roesky, M. Schmid, Polym. Chem. 2013, 4, 3077-3087.

S. M. Guillaume, L. Maron, P. W. Roesky in Catalytic behavior of rare-earth borohydride complexes in polymerization of polar monomers, Vol. 244 Eds.: J.-C. G. Bünzli, V. K. Pecharsky), Elsevier, Amsterdam, 2014, pp. 1-86.

S. M. Guillaume, M. Schappacher, A. Soum, Macromolecules, 2003, 36, 54-60.

N. Barros, P. Mountford, S. M. Guillaume, L. Maron Chem. Eur. J., 2008, 14, $5507-5518$.

F. A. Jaipuri, B. D. Bower, N. L. Pohl, Tetrahedron Asymmetry, 2003, 14, 3249-3252. 
44 M. Basko, A. Duda, S. Kazmierski, P. Kubisa, J. Polym. Sci., Polym. Chem., 2013, 51, 4873-4884.

45 A. Couffin, B. Martín-Vaca, D. Bourissou, C. Navarro, Polym. Chem., 2014, 5, 161-168.

46 S. M. Guillaume, J.-F. Carpentier, Catal. Sci. Techn. 2012, 2, 898-906.

47 N. Ajellal, J.-F. Carpentier, C. Guillaume, S. M. Guillaume, M. Helou, V. Poirier, Y. Sarazin, A. Trifonov, Dalton Trans., 2010, 39, 8363-8376.

48 The ROP mediated by $\mathrm{Bi}(\mathrm{OTf})_{3} / \mathrm{PPD}$ gave $M_{\mathrm{n}, \mathrm{NMR}}$ values for the precipitated polymer lower than $M_{\mathrm{n}, \text { theo }}$ along with slightly larger dispersity values, indicative of the slightly greater occurrence of undesirable transfer reactions, ${ }^{49}$ as compared to the neodymiumbased catalytic system.

49 Buchard, A.; Bakewell, C. M.; Weiner, J.; Williams, C. K. Top. Organomet. Chem., 2012, 39, 175-224. 


\section{Electronic Supplementary Information}

\section{Linear and Three-arm Star Hydroxytelechelic Poly(Benzyl $\beta$-Malolactonate)s:}

\section{A Straightforward One-step Synthesis through Ring-Opening Polymerization}

Ghislaine Barouti, ${ }^{\S}$ Cédric G. Jaffredo,${ }^{\S}$ and Sophie M. Guillaume ${ }^{49}$

Institut des Sciences Chimiques de Rennes, UMR 6226 CNRS - Université de Rennes 1, Campus de Beaulieu, F-35042 Rennes Cedex, France

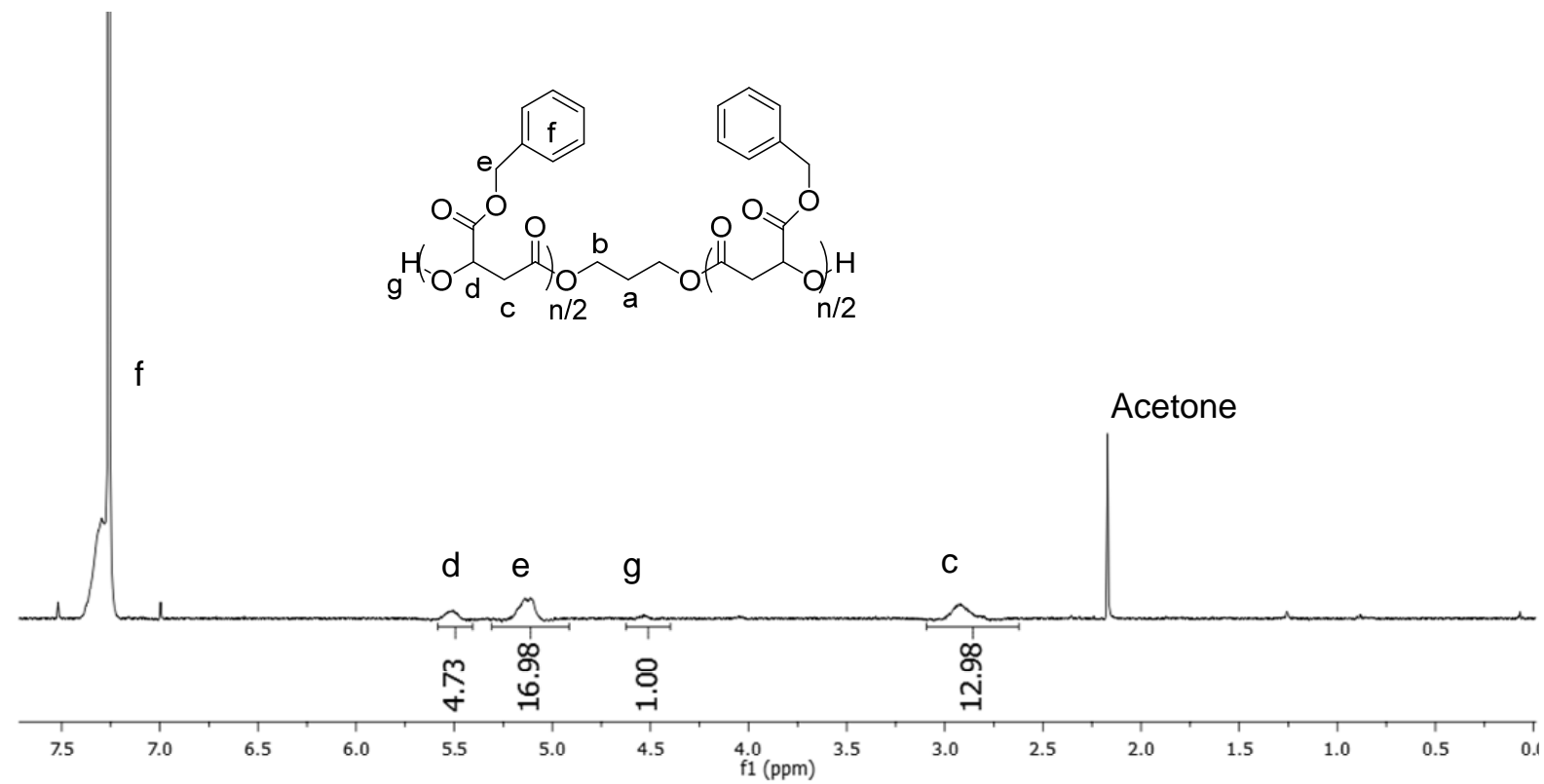

Figure S1. ${ }^{1} \mathrm{H}$ NMR spectrum $\left(\mathrm{CDCl}_{3}, 400 \mathrm{MHz}, 25^{\circ} \mathrm{C}\right)$ of a $\mathrm{PMLA}^{\mathrm{Be}}$ diol synthesized by ROP of MLA ${ }^{\mathrm{Be}}$ catalyzed by $\mathrm{Bi}(\mathrm{OTf})_{3}$ in presence of 5 equiv. of 1,3-propane diol as initiator (Table 1, entry 2). 


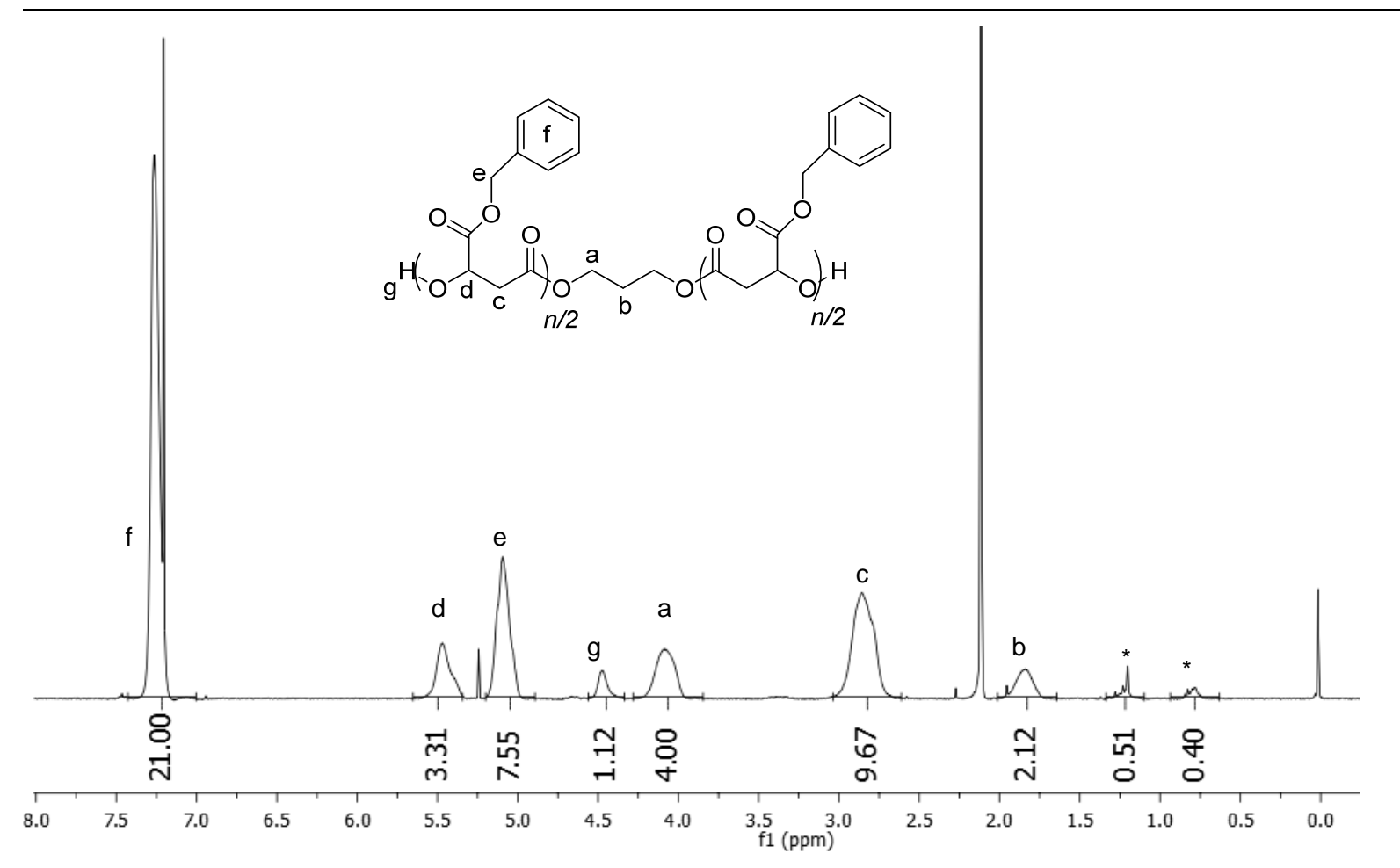

Figure S2. ${ }^{1} \mathrm{H}$ NMR spectrum $\left(\mathrm{CDCl}_{3}, 400 \mathrm{MHz}, 25^{\circ} \mathrm{C}\right)$ of a PMLA ${ }^{\mathrm{Be}}$ diol synthesized by ROP of MLA ${ }^{\mathrm{Be}}$ catalyzed by MSA in presence of 5 equiv. of 1,3-propane diol as initiator (Table 1, entry 13). 